\title{
Review
}

\section{Green reduction of graphene oxide involving extracts of plants from different taxonomy groups}

\author{
Dharshini Perumal ${ }^{1}$, Emmellie Laura Albert ${ }^{2}$ and Che Azurahanim Che Abdullah 1,2,3* \\ 1 Biophysics Laboratory, Department of Physics, Faculty of Science, Universiti Putra Malaysia 43400 Serdang, \\ Selangor, Malaysia; shinijessy@gmail.com \\ 2 Material Synthesis and Characterization Lab, Institute of Advanced Technology, Universiti Putra Malaysia, \\ 43400 Serdang, Selangor, Malaysia; emmellielaura@gmail.com \\ 2 UPM-MAKNA Cancer Research Laboratory, Institute of Bioscience, Universiti Putra Malaysia, 43400 Ser- \\ dang, Selangor, Malaysia; azurahanim@upm.edu.my \\ * Correspondence: azurahanim@upm.edu.my ; Tel.: +603-9769-6675
}

\begin{abstract}
Graphene is a remarkable material with numerous applications. Due to its thin and lightweight design, it is ideal for a variety of applications. The synthesis of high-quality graphene in a cost-effective and environmentally friendly manner continues to be a significant challenge. Chemical reduction is considered to be the most advantageous method for preparing reduced graphene oxide (rGO). However, this process necessitates the use of toxic and harmful substances, which can have a detrimental effect on the environment and human health. Thus, to accomplish the objective, the green synthesis principle has prompted researchers worldwide to develop a simple method for green reduction of graphene oxide (GO), which is readily accessible, sustainable, economical, renewable, and environmentally friendly in nature. For example, the use of natural materials such as plants is generally considered safe. Furthermore, plants contain reducing and capping agents. The current review will focus on the discovery and application of rGO synthesis using extracts from a variety of different parts of the plant. The review aims to aid current and future researchers in their search for a novel plant extract that acts as a reductant in the green synthesis of rGO. The review aims to assist current and future researchers in their research for a novel plant extract that acts as a reductant in the green synthesis of rGO as well as their potential applications in a variety of industries.
\end{abstract}

Keywords: Green synthesis; Plant extract; Reduced graphene oxide; Applications; Graphene oxide

\section{Introduction}

Since its discovery in 2004, graphene, a two-dimensional (2D) carbon atom bonded via $\mathrm{sp}^{2}$ hybridization, has garnered widespread recognition for its superior electrical, thermal, mechanical, and optical properties [1,2]. Thus, due to graphene's unique properties, it has been used in a variety of applications, including biosensors [3], drug delivery [4], solar cells [5], touch panels [6], anti-bacterial activities [7], photocatalytic degradation of pollutants [8]. Graphene has been synthesis using a variety of techniques over the last few years, including ultrasonic exfoliation, chemical vapor deposition, micro-mechanical exfoliation, epitaxial growth, and chemical reduction of GO via bottom-up and top-down approaches [9].

Among the methods used traditionally to prepare GO consists of the Brodie method, Staudenmaier method, and Hummer's method, as well as its variations, namely modified Hummer's method, or Improved Hummer's method, are all traditional methods for chemically preparing GO [10]. The most frequently used chemical methods for preparing GO and their characteristics are listed in Table 1. The Brodie method, invented in 1859, was the first to synthesize graphite oxide by adding potassium chlorate $\left(\mathrm{KClO}_{3}\right)$ to a mixture 
of graphite and fuming nitric acid $\left(\mathrm{HNO}_{3}\right)$. Later, the Staudenmaier method was refined based on the Brodie method, with the addition of an intercalant composed of sulphuric acid $\left(\mathrm{H}_{2} \mathrm{SO}_{4}\right)$ and $\mathrm{HNO}_{3}$. This method resulted in the efficient production of graphite oxide. Both methods, however, require a lengthy oxidation step that can last up to four days. In 1958, the Hummer method was widely adopted. It utilizes $\mathrm{H}_{2} \mathrm{SO}_{4}$ as an intercalant and $\mathrm{NaNO}_{3} / \mathrm{KMnO}_{4}$ as an oxidant. Although this method involves a faster oxidation step within two hours, it has been criticized for releasing toxic gases into the environment, such as $\mathrm{NO}_{2}$ and $\mathrm{N}_{2} \mathrm{O}_{4}$. Recently, an Improved Hummer's method was developed by omitting $\mathrm{NaNO}_{3}$ and substituting a 1:9 mixture of $\mathrm{H}_{2} \mathrm{SO}_{4}$ and $\mathrm{H}_{3} \mathrm{PO}_{4}$ for the sodium nitrate. This method results in a more oxidized graphite oxide with a more regular carbon structure and larger sheet size, while also avoiding the production of harmful gases [11].

Table 1. GO preparations made via chemical approach.

\begin{tabular}{|c|c|c|c|c|c|c|}
\hline Methods & Oxidants & $\begin{array}{c}\text { Reaction } \\
\text { time (h) }\end{array}$ & $\begin{array}{c}\text { Temperature } \\
\left({ }^{\circ} \mathrm{C}\right)\end{array}$ & Advantages & Drawbacks & Ref \\
\hline $\begin{array}{l}\text { Brodie } \\
\text { method }\end{array}$ & $\begin{array}{l}\mathrm{KClO}_{3} \\
\mathrm{HNO}_{3}\end{array}$ & $72-96$ & 60 & $\begin{array}{l}\text { - By oxidation, lay the } \\
\text { groundwork for graph- } \\
\text { ite delamination into } \\
\text { GO sheets }\end{array}$ & $\begin{array}{l}\text { - Longer time } \\
\text { - Possess a threat of } \\
\text { explosion } \\
\text { - Tedious prepara- } \\
\text { tion }\end{array}$ & {$[12]$} \\
\hline $\begin{array}{l}\text { Staudenmaier } \\
\text { method }\end{array}$ & $\begin{array}{l}\mathrm{HNO}_{3} \\
\mathrm{H}_{2} \mathrm{SO}_{4} \\
\mathrm{KClO} 3\end{array}$ & 96 & 90 & - Enhance the yield & $\begin{array}{l}\text { - Longer time } \\
\text { - Use of high tem- } \\
\text { perature } \\
\text { - Possess a threat of } \\
\text { explosion }\end{array}$ & [13] \\
\hline $\begin{array}{l}\text { Hummer's } \\
\text { method }\end{array}$ & $\begin{array}{c}\mathrm{NaNO}_{3} \\
\mathrm{H}_{2} \mathrm{SO}_{4} \\
\mathrm{KMnO}_{4}\end{array}$ & $\sim 2$ & 35,98 & $\begin{array}{l}\text { - Quicker } \\
\text { - No danger of explo- } \\
\text { sion } \\
\text { - High effectiveness } \\
\text { - High rate of return }\end{array}$ & 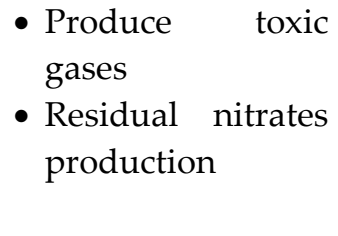 & {$[14]$} \\
\hline $\begin{array}{l}\text { Improved } \\
\text { Hummer's } \\
\text { method }\end{array}$ & $\begin{array}{c}\mathrm{KMnO}_{4} \\
\mathrm{H}_{3} \mathrm{PO}_{4} \\
\mathrm{H}_{2} \mathrm{SO}_{4}\end{array}$ & 12 & 50 & $\begin{array}{l}\text { - Temperature control } \\
\text { is possible } \\
\text { - Make carbon sub- } \\
\text { stances that is hydro- } \\
\text { philic } \\
\text { - Faults are reduced } \\
\text { - Free from emission of } \\
\text { - harmful gases } \\
\text { - High rate of return }\end{array}$ & $\begin{array}{l}\text { - Takes longer time } \\
\text { - Required twice as } \\
\text { much } \mathrm{KMnO}_{4} \text { and } \\
5.2 \text { times as much } \\
\mathrm{H}_{2} \mathrm{SO}_{4} \text { as those ap- } \\
\text { plied by Hum- } \\
\text { mer's method }\end{array}$ & [15] \\
\hline
\end{tabular}

Apart from its ease of synthesis, these oxygenated groups in GO confer a number of advantages over graphene, including increased solubility and the ability to customize the surface functionalization for specific applications, resulting in a plethora of applications in nanocomposite materials [16]. Regardless of the advantages, the oxygen-containing functional groups must be removed in order to restore graphene's fundamental properties, most notably its electrical conductivity [17]. The rGO are frequently referred to as a type of chemically synthesis graphene [18]. Numerous methods have been proposed for the preparation of rGO, including chemical, photo-mediated, thermal, and biological reduction [17]. Chemical reduction of exfoliated GO is the most frequently used method for producing rGO because it is cost-effective and can be produced in large quantities [19]. Chemical reduction of exfoliated GO is the most frequently used method for producing rGO due to its low cost and high yield. In general, this procedure consists of two steps. 
The method of oxidizing graphite powder to form graphite oxide and then adding reducing agents to form rGO is well-established [20].

Numerous strong chemicals reducing agents, including hydrazine [21], hydroquinone [22], dimethyl hydrazine, sodium borohydride $\left(\mathrm{NaBH}_{4}\right)$ [23], iron, tin powder [24] and zinc powder [25], have been used to synthesize rGO. However, the disadvantages of these chemical reduction agents include their high toxicity, the presence of trace amounts of potentially harmful agents, particularly in bio-related applications such as catalysis and drug delivery [26], and their impact on the environment. Additionally, on an industrial scale, the cost of treating the toxic waste generated by the reduction reaction may significantly increase. As a result, numerous studies have predicted the use of green reductants in the development of a novel environmentally friendly method for successfully converting GO to rGO under moderate conditions, in order to advance green technology. A green route is a simple, low-cost, non-toxic, and environmentally friendly procedure that makes use of materials and techniques that minimize the use and manufacture of hazardous compounds while avoiding the use of high temperatures and harsh reducing agents. Numerous phytochemicals derived from various parts of plants, such as the peel, root, seeds, leaves, and fruits, have been discovered to contain biomolecules. These biomolecules, which include proteins, polysaccharides, vitamins, pectin's, amino acids, alkaloids, polyphenols, and flavonoids, may act as capping and reducing agents during the green reduction and formation of functional rGO from GO $[27,28]$. Phenolics and flavonoids are the most abundant secondary metabolites and bioactive molecules found in plants, and they are excellent antioxidants [29].

As a result, this study compiles prior and current green rGO synthesis methods that outperform traditional methods and serve as a foundation for future sustainable material science research. Green synthesis is both cost effective and environmentally friendly, posing little or no pollution to the environment. The application of generated rGO have been summarized to provide a quick overview. Numerous plant extracts by parts have been reported to aid in the reduction of GO, as listed in Table 2.

Table 2. Summary of plant extract utilized in reduction of GO according to the category of their parts.

\begin{tabular}{|c|c|c|c|c|c|}
\hline No & Scientific name & Reduction method & $\begin{array}{c}\text { Reduction } \\
\text { temperature } \\
\left({ }^{\circ} \mathrm{C}\right) \\
\end{array}$ & $\begin{array}{l}\text { Reduction } \\
\text { time }\end{array}$ & Ref. \\
\hline \multicolumn{6}{|c|}{ Leaf extract } \\
\hline \multirow[t]{2}{*}{1} & Colocasia esculenta & - $\quad$ stir & RT & $8 \mathrm{~h}$ & [30] \\
\hline & & - reflux & 100 & $5 \mathrm{~h}$ & \\
\hline \multirow[t]{2}{*}{2} & Mesua ferrea Linn. & - $\quad$ stir & RT & $10 \mathrm{~h}$ & \\
\hline & & - reflux & 100 & $8 \mathrm{~h}$ & \\
\hline 3 & Spinacia oleracea & - stir & 30 & $24 \mathrm{~h}$ & [31] \\
\hline 4 & Ginkgo biloba & - stir & 37 & $24 \mathrm{~h}$ & [32] \\
\hline 5 & Eichhornia crassipes & - reflux & 100 & $10 \mathrm{~h}$ & [33] \\
\hline 6 & Pulicaria glutinosa & - reflux & 98 & $24 \mathrm{~h}$ & [34] \\
\hline \multirow[t]{7}{*}{7} & Prunus serrulate & - reflux & 95 & $12 \mathrm{~h}$ & [35] \\
\hline & Magnolia Kobus & & & & \\
\hline & Platanus orientalis & & & & \\
\hline & Diopyros kaki & & & & \\
\hline & Pinus desiflora & & & & \\
\hline & Acer palmatum & & & & \\
\hline & Ginkgo biloba & & & & \\
\hline \multirow[t]{2}{*}{8} & Azadirachta indica & - stir & RT & $48 \mathrm{~h}$ & [36] \\
\hline & & - reflux & 100 & $24 \mathrm{~h}$ & \\
\hline 9 & Euphorbia wallichii & - reflux & 100 & $6 \mathrm{~h}$ & [37] \\
\hline
\end{tabular}




\begin{tabular}{|c|c|c|c|c|c|}
\hline \multirow[t]{2}{*}{10} & \multirow[t]{2}{*}{ Nicotiana tabacum L. } & - $\quad$ stir & $\mathrm{RT}$ & $24 \mathrm{~h}$ & \multirow[t]{2}{*}[38]{} \\
\hline & & - reflux & 100 & $24 \mathrm{~h}$ & \\
\hline 11 & Spinacia oleracea & - reflux & 100 & $30 \mathrm{~min}$ & [39] \\
\hline \multirow[t]{3}{*}{12} & Ficus religiosa & - reflux & 50 & $24 \mathrm{~h}$ & [40] \\
\hline & Mangifera indica & & & & \\
\hline & Polyalthia longifolia & & & & \\
\hline 13 & Artemisia vulgaris & - reflux & 90 & $6 \mathrm{~h}, 12 \mathrm{~h}$ & [41] \\
\hline 14 & Paederia foetide L. & - $\quad$ stir & 50 & $12 \mathrm{~h}$ & [9] \\
\hline \multirow[t]{2}{*}{15} & Mangifera indica L. & - $\quad$ stir & 60 & $12 \mathrm{~h}$ & [42] \\
\hline & & - reflux & $60-70$ & $8 \mathrm{~h}$ & \\
\hline 16 & Platanus orientalis & - reflux & 100 & $10 \mathrm{~h}$ & [43] \\
\hline 17 & Olea europaea & - water bath & 100 & $10 \mathrm{~h}$ & [44] \\
\hline 18 & Melissa officinalis L. & - $\quad$ stir & $\mathrm{RT}$ & $12 \mathrm{~h}$ & [45] \\
\hline 19 & Annona squamosa & - reflux & 100 & $12 \mathrm{~h}$ & [46] \\
\hline 20 & Eucalyptus & - water bath & 80 & $8 \mathrm{~h}$ & [47] \\
\hline 21 & Lantana camara & - reflux & 50 & $6 \mathrm{~h}$ & [27] \\
\hline 22 & Camellia sinensis & - reflux & 90 & $1 \mathrm{~h}$ & [48] \\
\hline 23 & Citrullus colocynthis & - reflux & 100 & $14 \mathrm{~h}$ & [49] \\
\hline 24 & Aloe vera & - reflux & 95 & $24 \mathrm{~h}$ & {$[50]$} \\
\hline 25 & Aloe vera (L.) Burm.f. & - reflux & 80 & $5 \mathrm{~h}$ & [51] \\
\hline 26 & Ocimum sanctum & - reflux & 100 & $10 \mathrm{~h}$ & [28] \\
\hline 27 & Anacardium occidentale Linn & - $\quad$ stir & 68 & $3 \mathrm{~h}$ & [52] \\
\hline 28 & Eucalyptus & - reflux & 80 & $8 \mathrm{~h}$ & [53] \\
\hline 29 & Ocimum sanctum $L$. & - $\quad$ stir & 70 & $4 \mathrm{~h}$ & [54] \\
\hline 30 & Stigmaphyllon ovatum & - $\quad$ stir & $60-70$ & $24 \mathrm{~h}$ & [55] \\
\hline 31 & Euphorbia cheiradenia Boiss & - reflux & 80 & $7 \mathrm{~h}$ & [56] \\
\hline 32 & Mentha arvensis & - reflux & $80-95$ & $3 \mathrm{~h}$ & [57] \\
\hline \multirow[t]{2}{*}{33} & Tribulus terrestris & - $\quad$ autoclave & 180 & $12 \mathrm{~h}$ & [58] \\
\hline & Mentha piperita & & & & \\
\hline 34 & Camellia sinensis & - water bath & 80 & $8 \mathrm{~h}$ & [59] \\
\hline 35 & Urtica dioica L. & - $\quad$ stir & 90 & $1 \mathrm{~h}$ & [60] \\
\hline 36 & Euphorbia milli & - $\quad$ stir & RT & $48 \mathrm{~h}$ & [61] \\
\hline 37 & Thymbra spicata & - reflux & 100 & $12 \mathrm{~h}$ & [62] \\
\hline 38 & Euphorbia heterophylla (L.) & - reflux & 95 & $12 \mathrm{~h}$ & [63] \\
\hline 39 & Memecylon edule & - water bath & 60 & $12 \mathrm{~h}$ & [64] \\
\hline 40 & Elaeis guineensis & - reflux & 100 & $3 \mathrm{~h}$ & [65] \\
\hline 41 & Zataria multiflora & - reflux & 98 & $24 \mathrm{~h}$ & [66] \\
\hline 42 & Memecylon edule & - water bath & 60 & $12 \mathrm{~h}$ & [64] \\
\hline 43 & Azadirachta indica & - $\quad$ stir & 30 & $24 \mathrm{~h}$ & [67] \\
\hline \multicolumn{6}{|c|}{ Telfairia occidentalis } \\
\hline 45 & Murraya koenigii & - $\quad$ autoclave & 100 & $12 \mathrm{~h}$ & [68] \\
\hline 46 & $\begin{array}{l}\text { Cinnamomum camphora cine- } \\
\text { oliferum }\end{array}$ & - $\quad$ stir & RT & $24 \mathrm{~h}$ & [69] \\
\hline 47 & $\begin{array}{l}\text { Phyllarthrom madagascariese } \\
\text { K. Schum }\end{array}$ & & & & \\
\hline 48 & Acalypha indica & - $\quad$ autoclave & 100 & $12 \mathrm{~h}$ & [70] \\
\hline 49 & Erythrina senegalensis & - reflux & 95 & $24 \mathrm{~h}$ & [71] \\
\hline 50 & Callistemon viminalis & - $\quad$ stir & 60 & $2 \mathrm{~h}$ & [72] \\
\hline \multicolumn{6}{|c|}{ Fruit extract } \\
\hline 1 & Cocos nucifera $L$. & - oil bath & 80,100 & $\begin{array}{c}12 \mathrm{~h}, 24 \mathrm{~h}, \\
36 \mathrm{~h}\end{array}$ & [73] \\
\hline
\end{tabular}




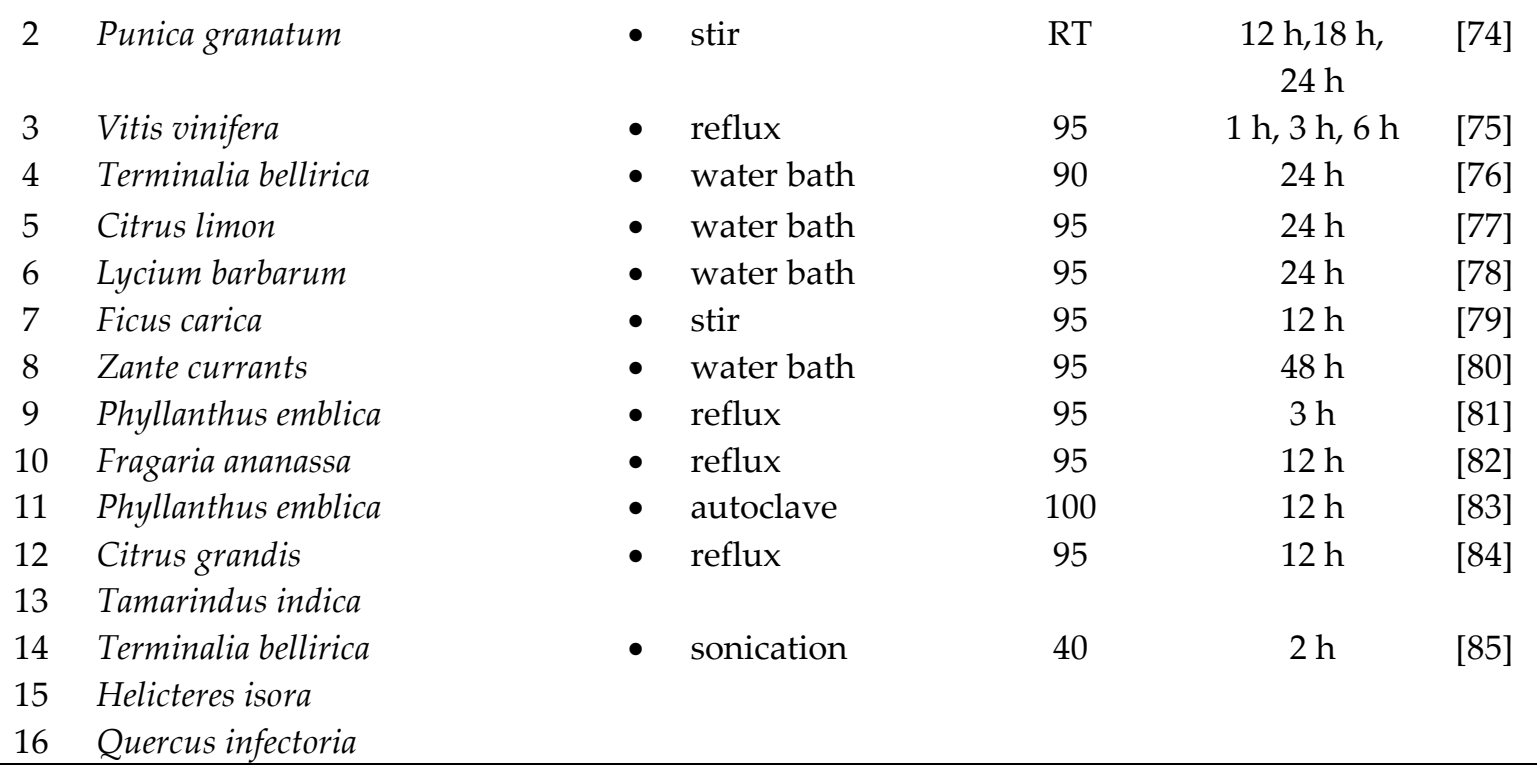

\begin{tabular}{|c|c|c|c|c|c|}
\hline \multicolumn{6}{|c|}{ Flower extract } \\
\hline 1 & Rosa damascena & - $\quad$ autoclave & 95 & $5 \mathrm{~h}$ & {$[86]$} \\
\hline 2 & Hibiscus sabdariffa L. & - $\quad$ stir & 100 & $1 \mathrm{~h}$ & {$[87]$} \\
\hline 3 & Syzygium aromaticum & - reflux & 100 & $30 \mathrm{~min}$ & {$[88]$} \\
\hline 4 & Chrysanthemum morifolium & - water bath & 95 & $24 \mathrm{~h}$ & [89] \\
\hline 5 & Tagetes erecta & - $\quad$ stir & 95 & $3 \mathrm{~h}$ & [90] \\
\hline \multicolumn{6}{|c|}{ Peel extract } \\
\hline \multirow[t]{2}{*}{1} & Citrus sinensis & - $\quad$ stir & RT & $10 \mathrm{~h}$ & {$[30]$} \\
\hline & & - reflux & 100 & $8 \mathrm{~h}$ & \\
\hline 2 & Citrus limeta & - reflux & 50 & $6 \mathrm{~h}$ & [27] \\
\hline 3 & Sugarcane bagasse & - $\quad$ stir & 95 & $12 \mathrm{~h}$ & [91] \\
\hline 4 & Citrus hystrix & - $\quad$ stir & RT & $8 \mathrm{~h}$ & [92] \\
\hline \multicolumn{6}{|c|}{ Bark/Stem extract } \\
\hline 1 & Cinnamomum zeylanicum & - $\quad$ reflux & 100 & $45 \min$ & {$[93]$} \\
\hline 2 & Cinnamomum verum & - reflux & 100 & $12 \mathrm{~h}$ & [94] \\
\hline \multirow[t]{2}{*}{3} & Saccharum officinarum & - stir & 50 & $3 \mathrm{~h}$ & [95] \\
\hline & & - autoclave & 150 & $12 \mathrm{~h}$ & \\
\hline 4 & Cedrelopsis grevei Baill & - $\quad$ stir & RT & $24 \mathrm{~h}$ & [69] \\
\hline 5 & Alstonia scholaris & - $\quad$ stir & 90 & $1 \mathrm{~h}, 3 \mathrm{~h}$ & [96] \\
\hline \multicolumn{6}{|c|}{ Seed extract } \\
\hline 1 & Phaseolus aureus L. & stir & 30 & $24 \mathrm{~h}$ & [97] \\
\hline 2 & Terminalia chebula & reflux & 90 & $24 \mathrm{~h}$ & [98] \\
\hline 3 & Glycine max (L.) Merr. & stir & $75,85,95$ & $1 \mathrm{~h}$ & {$[99]$} \\
\hline 4 & Vitis vinifera & stir & RT & $10 \mathrm{~h}$ & [100] \\
\hline 5 & Punica grantum & stir & 98 & $8 \mathrm{~h}$ & [101] \\
\hline \multicolumn{6}{|c|}{ Root extract } \\
\hline \multirow[t]{2}{*}{1} & Daucus carota & - $\quad$ stir & RT & $48 \mathrm{~h}$ & [102] \\
\hline & & - reflux & 100 & $24 \mathrm{~h}$ & \\
\hline \multirow[t]{2}{*}{2} & Asian red ginseng & $\begin{array}{l}\text { - } \quad \text { stirring in the } \\
\text { presence of Fe }\end{array}$ & 80 & $10 \mathrm{~min}$ & [103] \\
\hline & & $\begin{array}{l}\text { foil as a cata- } \\
\text { lyst }\end{array}$ & & & \\
\hline 3 & Daucus carota subsp. sativus & - stir & 90 & $1 \mathrm{~h}$ & [104] \\
\hline 4 & Salvadora persica L. (miswak) & - reflux & 98 & $24 \mathrm{~h}$ & {$[105]$} \\
\hline
\end{tabular}




\begin{tabular}{|c|c|c|c|c|c|}
\hline 5 & Solanum tuberosum L. (po- & - Stir & 60 & $12 \mathrm{~h}$ & {$[42]$} \\
\hline & tato) & - reflux & $70-80$ & $8 \mathrm{~h}$ & \\
\hline 6 & Allium ascalonicum (shallot) & - stir & RT & $72 \mathrm{~h}$ & [106] \\
\hline 7 & Allium сера (onion) & - stir & RT & $6 \mathrm{~h}$ & [107] \\
\hline 8 & Catharanthus roseus & - precipitation & RT & $24 \mathrm{~h}$ & [69] \\
\hline 9 & Raphanus sativus & - $\quad$ autoclave & 100 & $12 \mathrm{~h}$ & {$[70]$} \\
\hline 10 & Zingiber officinale Roscoe & - reflux & 90 & $\begin{array}{c}4 \text { h, } 6 \text { h, } 8 \\
\text { h, } 10 \text { h, } 12 \text { h }\end{array}$ & {$[108]$} \\
\hline 11 & Acorus calamus & - $\quad$ sonication & 40 & $2 \mathrm{~h}$ & [85] \\
\hline \multicolumn{6}{|c|}{ Pollen grain extract } \\
\hline \multirow[t]{4}{*}{1} & Peltophorum pterocarpum & - stir & RT & $24 \mathrm{~h}$ & {$[109]$} \\
\hline & & $\begin{array}{l}\text { - heat-treated in } \\
\text { an Ar gas }\end{array}$ & 450 & $90 \mathrm{~min}$ & \\
\hline & & - reflux & 120 & $30 \mathrm{~h}$ & \\
\hline & & $\begin{array}{l}\text { - heat-treated in } \\
\text { an Ar gas }\end{array}$ & 550 & $2 \mathrm{~h}$ & \\
\hline
\end{tabular}

\section{Preparation of Aqueous Extracts of Plants}

The interest portion of a plant was collected from local areas. The components were thoroughly cleaned to remove dust particles. Then it was either used fresh or dried under an air atmosphere, in the sun, or in an oven to remove the moisture. Following that, the dried components were ground into a fine powder using a mortar and pestle or a household blender. In order to prepare the extract, the powder or freshly chopped pieces were dispersed in distilled water and the solution was gradually heated using a magnetic stirrer, reflux, or Soxhlet apparatus. After allowing the mixture to cool to room temperature, it was filtered using filter paper to remove the bulk waste. The supernatant was collected and centrifuges in order to remove any detritus from the solution. The resulting filtrate was refrigerated and used to further reduce GO, as shown in Figure 1.

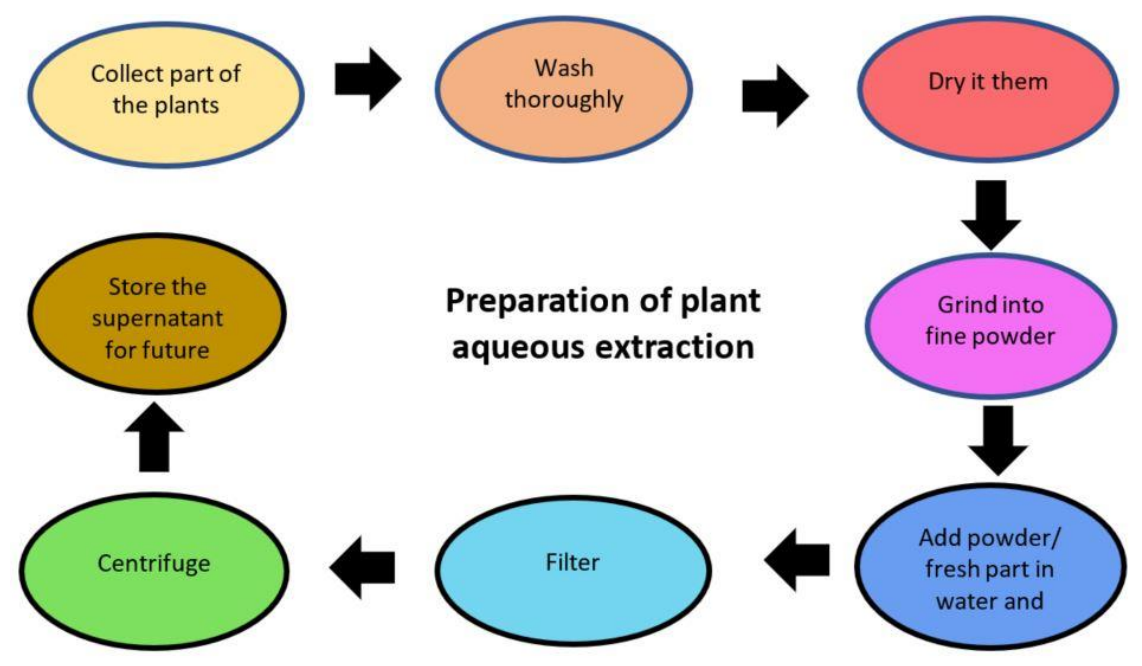

Figure 1. Preparation of plant aqueous extracts for the green synthesis of rGO using plant extracts

\section{The synthesis of rGO}

As illustrated in Figure 2, this synthesis procedure consists of two steps. To begin, GO was prepared from graphite powder as a precursor. Second, deoxygenating agents 
are used to reduce the oxygen functional groups on the GO sheets. While water and other organic solvents such as ethylene glycol, N, N-dimethyl formamide, and N-methyl pyrrolidine have been used to disperse GO, water is the most frequently used [110]. Sonication or magnetic stirring were used to exfoliate the GO and create a homogeneous dispersion $[21,111]$. The yellow-brown solution that resulted was used for reduction with plant extracts. The mixture will then be subjected to reflux, autoclave, or stirring at a controlled temperature of $24^{\circ} \mathrm{C}$ to $180^{\circ} \mathrm{C}$ for a duration of between $30 \mathrm{~min}$ to $72 \mathrm{~h}$ based on previous studies. Adjusting the $\mathrm{pH}$ of the reaction solution with diluted sodium hydroxide $(\mathrm{NaOH})$, hydrochloric acid $(\mathrm{HCl})$, or ammonium hydroxide $\left(\mathrm{NH}_{4} \mathrm{OH}\right)$ is also critical, as the reduction can occur in both acidic and alkaline environments [112]. Thus, according to a review of green reduction using plant extracts, the $\mathrm{pH}$ of the solution is primarily regulated using $\mathrm{NH}_{4} \mathrm{OH}[43,44,98,49,60,64,75,76,79,80,94]$. Bosch and colleagues demonstrated the effect of various $\mathrm{pH}$ values on the final production of GO sheets. The results indicated that the reduction process carried out in an alkaline environment promotes the formation of minimal defects in the resulting rGO [113]. A change in the color of the solution from brownish to black indicates that the GO has been successfully deoxygenated. The solution is then filtered or centrifuged to obtain the black solid. The black solid is washed several times with water or alcohol to remove any impurities or plant residues. Finally, the collected black solid is allowed to dry at room temperature, in an oven, or in a vacuum freeze dryer. The resulting compound was designated as rGO.

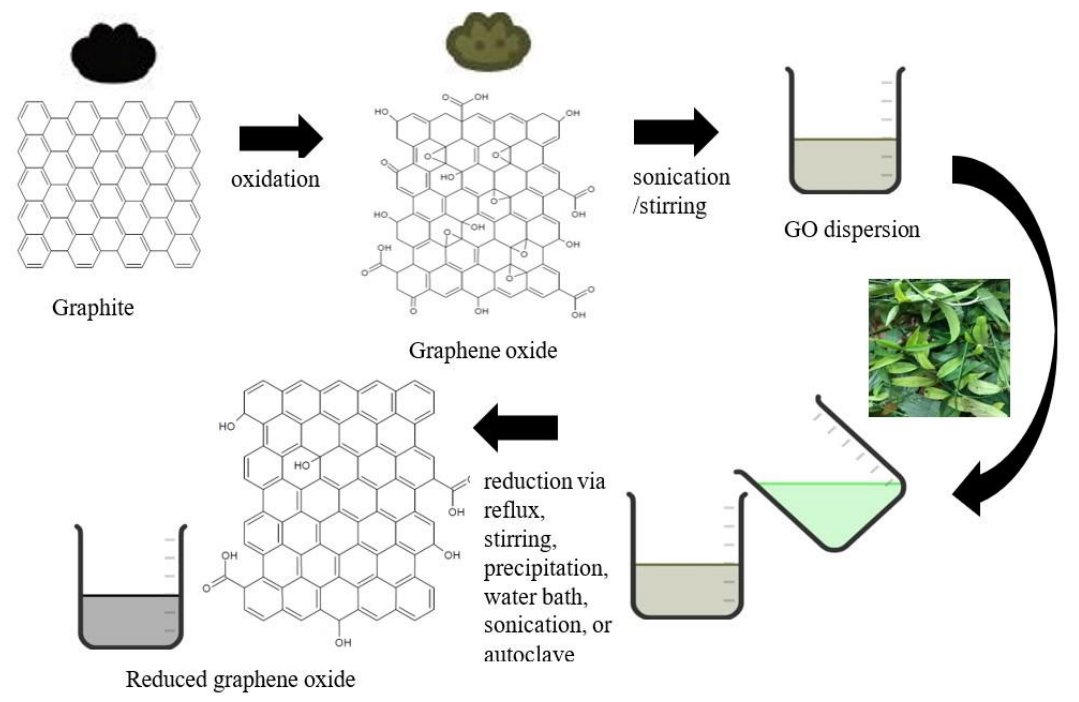

Figure 2. Schematic diagram of various steps involved in the synthesis of rGO.

\section{Applications}

The synthesis of rGO from natural and renewable resources is a vibrant and exciting area of research. As previously stated, eco-friendly routes were developed by fusing green chemistry principles with nanotechnology to create biocompatible and bioactive nanodevices for a variety of applications, including photocatalysts, biomedical, sensors, supercapacitors, and etc.

\subsection{Biomedical applications}

There are several reports in the literature describing biomedical applications of green synthesis rGO. Gurunathan and co-workers have shown a successful reduction of GO using spinach leaf extract (S-rGO) that has significant biocompatibility with primary mouse embryonic fibroblast (PMEF) cells in various assays including cell viability, lactate dehydrogenase (LDH) leakage and alkaline phosphate (ALP) activity [31]. Similarly, they 
synthesis graphene using Ginkgo biloba extract (Gb-rGO) and evaluated its biocompatibility in human breast cancer cells (MDA-MB-231) using a series of assays including cell viability, apoptosis and ALP activity [32]. On the LDH leakage activity, the biocompatibility of S-rGO treated PMEF cells shows no obvious differences even at higher concentrations. The cytocompatibility of Gb-rGO treated MDA-MB-231 cancer cells were determined using the TUNEL assay. Round and homogeneous nuclei cells were observed, with no TUNEL-positive cells. ALP is a membrane-bound enzyme involved in the mineralization of skeletal tissues; its activity has been used as a quantitative marker of osteoblastic differentiation [114]. It was demonstrated that S-rGO treated PMEF cells and Gb-rGO treated MDA-MB-231 cancer cells enhanced ALP activity. S-rGO treated PMEF cells and Gb-rGO treated MDA-MB-231 cancer cells had no significant inhibitory effect on cell viability, even at the highest concentration $(100 \mu \mathrm{g} / \mathrm{mL})$.

The in vitro cytotoxicity of biosynthesis rGO using Platanus orientalis leaf extract against Catla catla cardiac cell lines $(\mathrm{SICH})$ at various concentration $(3 \mu \mathrm{g} / \mathrm{mL}-72 \mu \mathrm{g} / \mathrm{mL})$ [43], rGO using Erythrina senegalensis leaf extract against SICH cell lines at various concentrations $(10 \mu \mathrm{g} / \mathrm{mL}-100 \mu \mathrm{g} / \mathrm{mL})$ [71] and synthesis of rGO using leaf extract of Citrullus colocynthis against human prostate cancer (DU 145) cell lines at various concentration ( $4 \mathrm{mg} / \mathrm{mL}$ to $80 \mathrm{mg} / \mathrm{mL}$ ) exhibited a dose-dependent toxicity [49]. Shuba and colleagues demonstrated the synthesis of rGO using an Ocimum sanctum hydroalcoholic extract (ORGO). ORGO had a lower heamolytic activity (4.3\%) on suspended red blood cells from fresh chicken blood than GO at the highest concentration tested $(10 \mu \mathrm{g} / \mathrm{mL})$. ORGO treatment of mouse embryonic fibroblast cells (Balb 3T3 cells) at various concentrations inhibited cell growth by $29 \%$ [28]. The cytotoxicity of rGO loaded with paclitaxel synthesis from Euphorbia milli leaves against human lung cancer cell lines (A549) decreased with increasing concentration ( 0 to $500 \mu \mathrm{g} / \mathrm{mL}$ ). The free rGO exhibited negligible cytotoxicity toward A549 cell lines [61]. The in vitro cytotoxicity of rGO nanosheets derived from Euphorbia heterophylla (L.) leaf extracts against cancerous cell lines such as Human Hepatocarcinoma (HepG2) and A549 cell lines decreases with increasing concentration (0 to 400 $\mu \mathrm{g} / \mathrm{mL}$ ). The mechanism of action of rGO against cancer cell lines is unknown. They may interact with the plasma membrane or extracellular matrix and enter the cell primarily via diffusion, endocytosis, and/or binding to receptors [63].

Wang et al. [64] demonstrated the synthesis of rGO from Memecylon edule leaf extracts, which has the potential to be used as a photothermal therapeutic agent for cancer cell apoptosis. Even at the highest concentration $(1 \mathrm{mg} / \mathrm{mL})$, the biocompatibility of rGO synthesis was independent of the concentration and resulted in cell viability of $>98 \%$ in the Madin-Darby Canine Kidney (MDCK) and A549 cell lines examined. However, when cells were exposed to near infrared light, rGO treated A549 cells demonstrated a rapid decline (from $65 \%$ to $35 \%$ ), whereas rGO treated MDCK cells demonstrated a slow decline in viability (from $90 \%$ to $65 \%$ ). Thus, upon NIR irradiation, the PTT agents emitted the greatest amount of photothermal heat within the tumor atmosphere, resulting in the greatest photothermal cytotoxicity to the A549 cells. In comparison, PTT agents exhibited the least photothermal cytotoxicity on typical MDCK cells due to the absence of a responsive atmosphere.

Punniyakotti et al. [70] investigated the deoxygenation of GO using two distinct types of green extracts, Acalypha indica (AIrGO) and Raphanus sativus (RSrGO), and their anticancer activity against human breast (MCF-7) and A549 cancer cell lines. Cell inhibition was $61.34 \%$ (IC50 $38.46 \mu \mathrm{g} / \mathrm{mL}$ ) for AIrGO treated A549 cell and $65.84 \%$ (IC50 26.69 $\mu \mathrm{g} / \mathrm{mL})$ for RSrGO treated A549 cells at the maximum concentration $(100 \mu \mathrm{g} / \mathrm{mL})$. At a concentration of $100 \mu \mathrm{g} / \mathrm{mL}$, AIrGO inhibited MCF-7 cells by $68.55 \%$ (IC50 $35.97 \mu \mathrm{g} / \mathrm{mL}$ ) and RSrGO inhibited MCF-7 cells by $71.15 \%$ (IC50 $33.22 \mu \mathrm{g} / \mathrm{mL}$ ). Acorus calamus (ACCARGO), Terminalia bellirica (TBRGO), Helicteres isora (HIRGO) and Quercus infectoria (QIRGO) rGO-mediated herbal plant extracts exhibit significant concentration-dependent cytotoxicity against MCF-7 cell lines [85]. ACARGO inhibits cell growth by $20.2 \%$ (IC50 81 $\mu \mathrm{g} / \mathrm{mL}$ ), TBRGO by 26\% (IC $50120 \mu \mathrm{g} / \mathrm{mL}$ ), HIRGO by 30\% (IC $5092 \mu \mathrm{g} / \mathrm{mL}$ ), and QIRGO by $31.1 \%$ (IC $5087 \mu \mathrm{g} / \mathrm{mL})$. 
The anti-tuberculosis activity of rGO synthesis from Cinnamomum verum bark extracts was demonstrated against Mycobacterium tuberculosis H37Ra (M. tuberculosis H37Ra) [94]. The MABA assay demonstrated that rGO-treated M. tuberculosis H37Ra exhibits antituberculosis activity at $200 \mu \mathrm{g} / \mathrm{mL}$. Yaragalla et al. [100] demonstrated the deoxygenation of GO using grape seed extract and evaluated its antimicrobial and anti-proliferation activity. Antibacterial activity of rGO against Staphylococcus aureus (S. aureus) and Escherichia coli (E. coli) at various concentrations revealed that bacteria were completely killed at the higher concentrations ( $4 \& 5 \mu \mathrm{g} / \mathrm{mL}$ ). Heat-induced inflammatory activity as measured by aspirin (standard drug) and rGO on RBC suspension reveals no statistically significant differences, with rGO demonstrating $39.83 \%$ activity and aspirin demonstrating $41.34 \%$ activity. The in vitro anti-proliferation activity of rGO on human colon carcinoma (HCT116) cell lines was found to be approximately $88 \%$ effective at the highest concentration $(500 \mu \mathrm{g} / \mathrm{mL})$ within 24 hours.

In 2019, Khanam and Hasan synthesis graphene from Allium cepa (onion) extracts and evaluated its antibacterial properties against two gram-negative bacteria (E. coli and Pseudomonas aeruginosa) as well as gram-positive bacteria (Streptococcus faecalis and S. aureus $)$. The percentage loss of cell viability on the $5^{\text {th }}$ day $(120 \mathrm{~h})$ is $90.5 \%$ for E. coli treated with rGO, $93.1 \%$ for P. aeruginosa treated with rGO, $94 \%$ for S. faecalis treated with rGO, and $95 \%$ for $S$. aureus treated rGO. As a result, the results indicate that antibacterial activity was more effective against gram-positive bacterial cells [107]. Akhavan and colleagues in 2013, demonstrated that rGO mediated by Asian red ginseng promotes human neural stem cells (hNSCs) attachment and proliferation due to the presence of ginsenosides (a potent antioxidant) on the surface of the rGO sheet. Additionally, using immunofluorescence imaging as an evaluation tool, ginseng-rGO films were shown to exhibit greater differentiation of hNSCs into neurons rather than glial cells [103]. Table 3 below listed the biomedical application of green rGO using various plant extracts as well as their bioactivity (cytotoxicity, anti-microbial, anti-tuberculosis, and anti-proliferative).

Table 3. Summarized the biocompatibility of rGO synthesis using cytotoxicity, anti-microbial, anti-tuberculosis, and anti-proliferative properties.

\begin{tabular}{|c|c|c|c|c|c|c|c|c|}
\hline $\begin{array}{l}\text { Scientific } \\
\text { name }\end{array}$ & Activity & Cell lines & Strain & MIC & Concentration & $\begin{array}{c}\text { Cell viabil- } \\
\text { ity } \\
(\%)\end{array}$ & $\mathrm{IC}_{50}$ & Ref. \\
\hline $\begin{array}{l}\text { Spinacia } \\
\text { oleracea }\end{array}$ & Cytotoxicity & $\begin{array}{l}\text { - Primary } \\
\text { mouse } \\
\text { embry- } \\
\text { onic fi- } \\
\text { broblast } \\
\text { (PMEF) }\end{array}$ & - NA & NA & - $10-100 \mu \mathrm{g} / \mathrm{mL}$ & - 100 & - NA & [31] \\
\hline $\begin{array}{l}\text { Citrullus } \\
\text { colocynthis }\end{array}$ & Cytotoxicity & $\begin{array}{l}\text { Prostate } \\
\text { cancer } \\
\text { (DU 145) }\end{array}$ & - NA & NA & $\begin{array}{l}\text { - } 4 \mathrm{mg} / \mathrm{mL} \\
\text { - } 8 \mathrm{mg} / \mathrm{mL} \\
\text { - } 40 \mathrm{mg} / \mathrm{mL} \\
\text { - } 80 \mathrm{mg} / \mathrm{mL}\end{array}$ & $\begin{array}{l}-86 \\
-70 \\
-36 \\
-20\end{array}$ & - NA & [49] \\
\hline $\begin{array}{l}\text { Ocimum } \\
\text { sanctum }\end{array}$ & Cytotoxicity & $\begin{array}{l}\text { - Mouse } \\
\text { fibro- } \\
\text { blast } \\
\text { (Balb } \\
\text { 3T3) }\end{array}$ & - NA & NA & - $10 \mu \mathrm{L}$ & - 29 & - NA & [28] \\
\hline $\begin{array}{c}\text { Euphorbia } \\
\text { milli }\end{array}$ & $\begin{array}{l}\text { Anticancer ef- } \\
\text { fect of rGO } \\
\text { loaded } \\
\text { paclitaxel }\end{array}$ & $\begin{array}{l}\text { - Lung } \\
\text { cancer } \\
\text { (A549) }\end{array}$ & - NA & NA & $\begin{array}{l}\text { - } 200 \mu \mathrm{g} / \mathrm{mL} \\
\text { - } 500 \mu \mathrm{g} / \mathrm{mL}\end{array}$ & $\begin{array}{l}-29 \\
\text { - } 10\end{array}$ & - NA & [61] \\
\hline
\end{tabular}




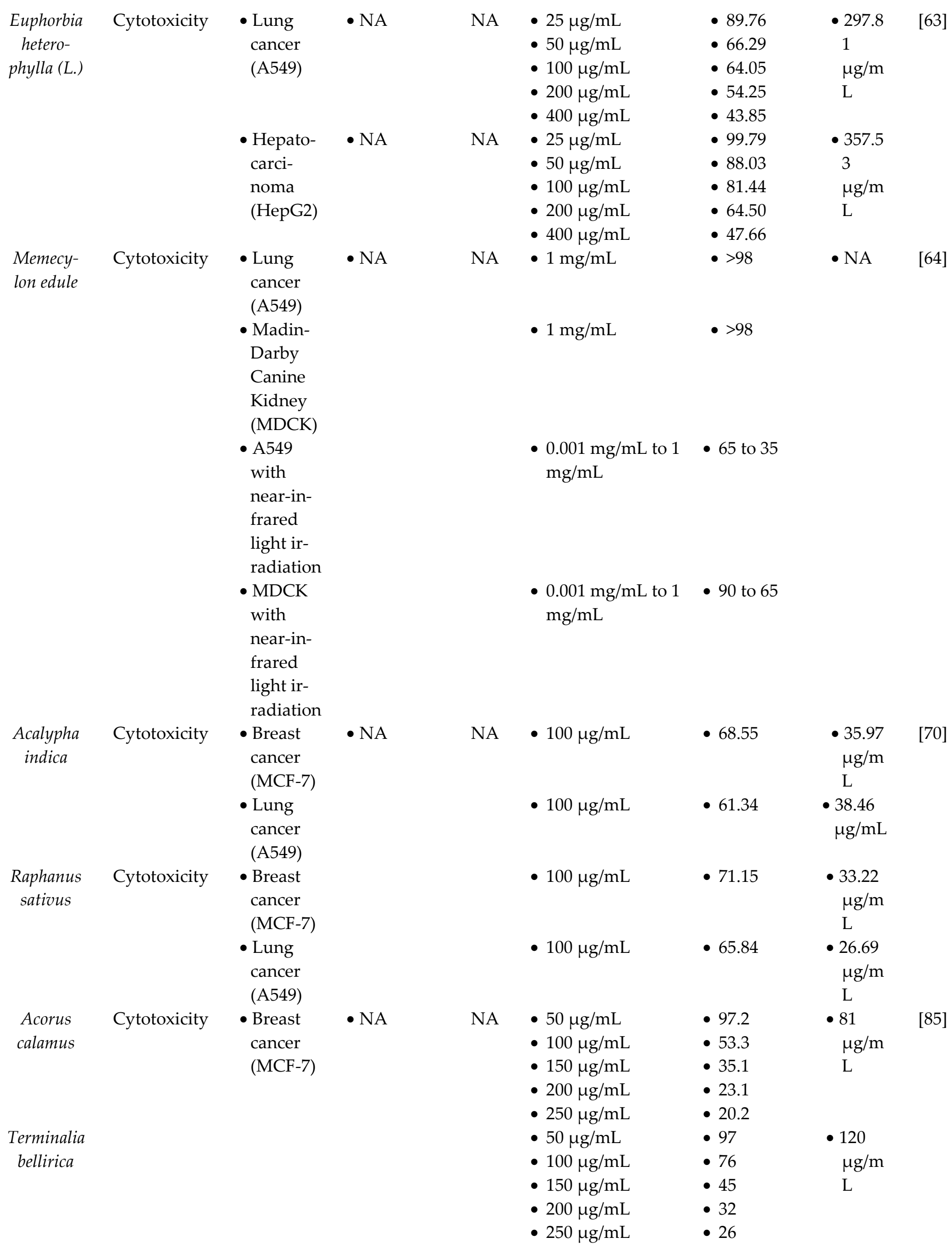




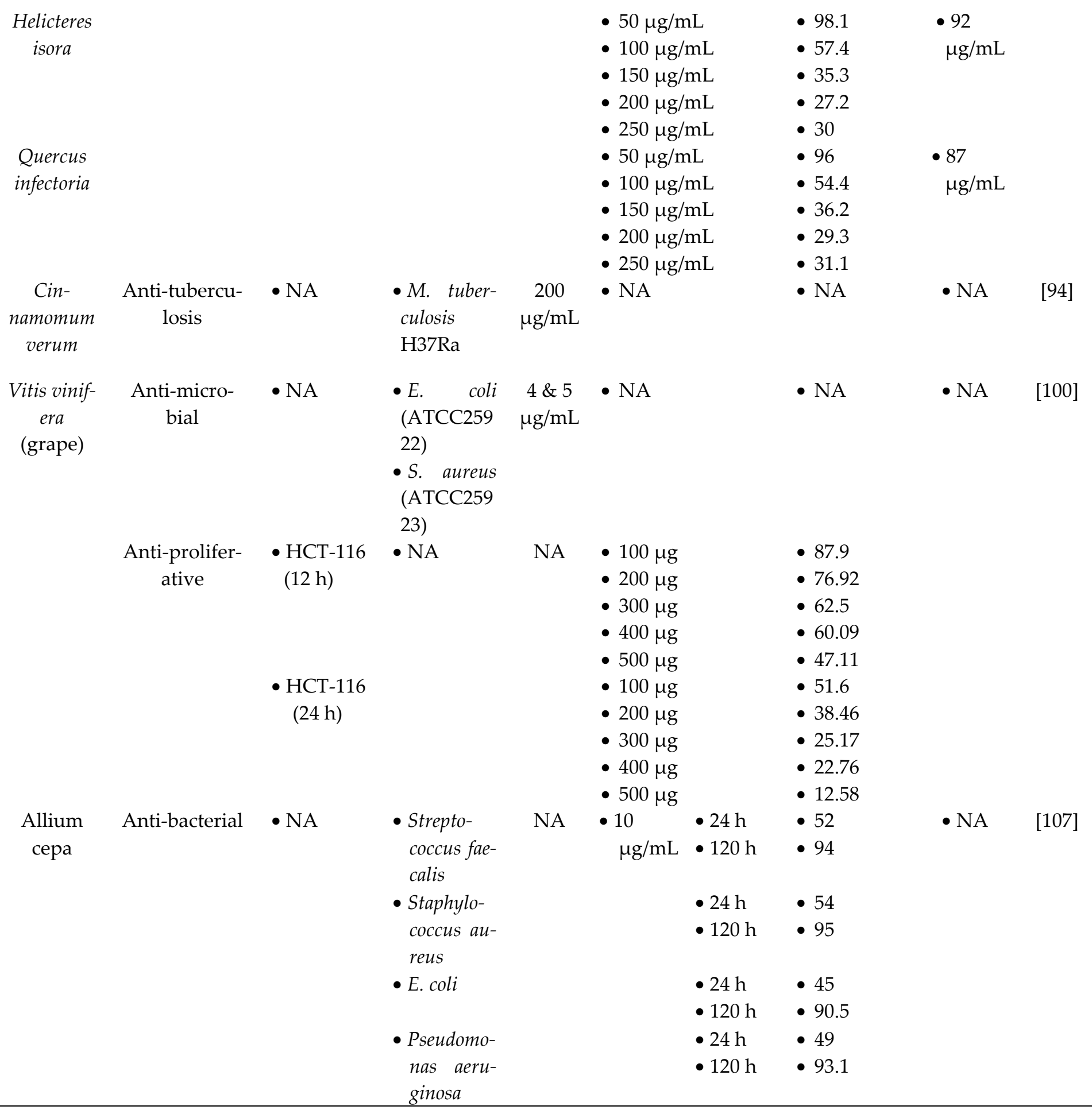

\subsection{Supercapacitors}

There are several reports in the literature describing supercapacitors applications of green synthesis rGO. Chu and colleagues (2014) demonstrated the synthesize of rGO from an aqueous extract of Hibiscus sabdariffa L. (HRGO) that was used to fabricate a flexible graphene film electrode. The electrical conductivity of the HRGO electrodes was significantly increased over four orders of magnitude by treating them in a household microwave oven (MW-HRGO-R). The electrode's specific capacitance increased as the scan rate decreased for both the HRGO-R and MW-HRGO-R cell [87]. The green reduction of GO and the fabrication of an open porous structure are accomplished simultaneously in a onepot process utilizing an aqueous seed extract of Glycine Max (L.) Merr. and the presence of 
protein gelation, designated as BRGO and BRGO-H. BRGO-H exhibited excellent electrical conductivity, a high swelling ratio, and an opening porous structure, and graphene coated with soybean proteins was used as a starting material for the fabrication of graphene-based porous electrodes. To further improve the electrode's electrical conductivity and efficiency, BRGO-H was microwave-treated to form a graphene-based nanocomposite. Thus, electrical conductivity was increased approximately four orders of magnitude, electroactive surface area was increased more than fourfold, and increased specific capacitance indicates a promising application for supercapacitor electrodes [99].

Jana and coworkers (2014) demonstrated that rGO synthesis from mung beans (Phaseolus aureus L.) soaked water has a high specific capacitance and excellent electrochemical cyclic stability, making it an excellent candidate for supercapacitor electrode materials [97]. Another study by a similar group demonstrated that rGO synthesis from tobacco solution at a temperature of $100^{\circ} \mathrm{C}$ outperforms rGO synthesis at room temperature as supercapacitor electrode materials [38]. Green synthesis rGO prepared from Peltophorum pterocarpum pollen grains demonstrated excellent electrochemical properties with a maximum specific capacitance of $27.1 \mathrm{~F} \mathrm{~g}^{-1}$, which has the potential to be used to fabricate bilayer capacitors [109]. The electrochemical properties of Aloe vera (L.) Burm. f. extract containing rGO reveal a specific capacitance of $142 \mathrm{~F} \mathrm{~g}^{-1}$ (at a scan rate of $5 \mathrm{mV} \mathrm{s}^{-1}$ ), a galvanostatic charge-discharge capacitance of $267 \mathrm{~F} \mathrm{~g} \mathrm{~g}^{-1}$ (at a current density $1 \mathrm{~A} \mathrm{~g}^{-1}$ ), and a cyclic stability capacitance of $158 \mathrm{~F} \mathrm{~g}^{-1}$ for 1000 cycles. The electrochemical results of rGO demonstrate a high potential for developing electrodes for supercapacitor-based energy storage devices [51].

Raja et al. (2019) demonstrated the electrochemical performance of rGO using strawberry extract. They discovered that as the scan rate decreases, the specific capacitance increases from $39.4 \mathrm{~F} \mathrm{~g}^{-1}$ at the scan rate $50 \mathrm{mV} \mathrm{s}^{-1}$ to $230.4 \mathrm{~F} \mathrm{~g}^{-1}$ at the scan rate $10 \mathrm{mV} \mathrm{s}^{-1}$. Additionally, the rGO retains $81 \%$ of its specific capacitance after 500 cycles [89]. Deoxygenation of GO using Citrus grandis and Tamarindus indica reveals excellent conductivity (47.33 F g-1 and 65.25 $\mathrm{F} \mathrm{g}^{-1}$ respectively) and high specific capacitance (4090 $\mathrm{Sm}^{-1}$ and 5545 $\mathrm{Sm}^{-1}$ respectively) makes them a suitable material for supercapacitor applications [84]. The rGO employed aqueous ginger extract refluxed at $90^{\circ} \mathrm{C}$ for 12 hours demonstrated excellent electrical conductivity, the highest specific capacitance value, and charge-discharge cyclic stability. The rGO material has the potential to be mass produced and used as an electrode material for supercapacitors [108]. Table 4 showed the summary of the electrochemical performance the synthesis rGO.

Table 4. summarized the electrochemical performances of synthesis rGO.

\begin{tabular}{|c|c|c|c|c|}
\hline Scientific name & Resistance & Specific capacitance & $\begin{array}{c}\text { Charge-discharge cyclic } \\
\text { stability }\end{array}$ & Ref. \\
\hline Hibiscus sabdariffa L. & $\begin{array}{l}\text { - } \text { Before microwave } \\
\text { - } 0.63 \mathrm{M} \Omega / \mathrm{sq} \text { sheet } \\
\text { resistance } \\
\text { - } \text { After microwave } \\
\text { - } 36.50 \mathrm{M} \Omega / \mathrm{sq} \text { sheet } \\
\text { resistance }\end{array}$ & - $204.38 \mathrm{~F} \mathrm{~g}^{-1}$ at $5 \mathrm{mVs}^{-1}$ & NA & [87] \\
\hline Phaseolus aureus L. & $\begin{array}{l}\text { - } 10 \Omega \text { solution re- } \\
\text { sistance }\end{array}$ & - $137 \mathrm{~F} \mathrm{~g}^{-1}$ at $1.3 \mathrm{~A} \mathrm{~g}^{-1}$ & $98 \%$ after 1000 cycles & [97] \\
\hline Nicotiana tabacum & $\begin{array}{l}\text { - } 4.20 \Omega \text { solution re- } \\
\text { sistance }\end{array}$ & - $206 \mathrm{~F} \mathrm{~g}^{-1}$ at $0.16 \mathrm{~A} \mathrm{~g}^{-1}$ & 112\% after 1000 cycles & [38] \\
\hline $\begin{array}{l}\text { Peltophorum ptero- } \\
\text { carpum }\end{array}$ & $\bullet$ NA & - $27.1 \mathrm{~F} \mathrm{~g}^{-1}$ at $5 \mathrm{mVs}^{-1}$ & NA & [109] \\
\hline
\end{tabular}




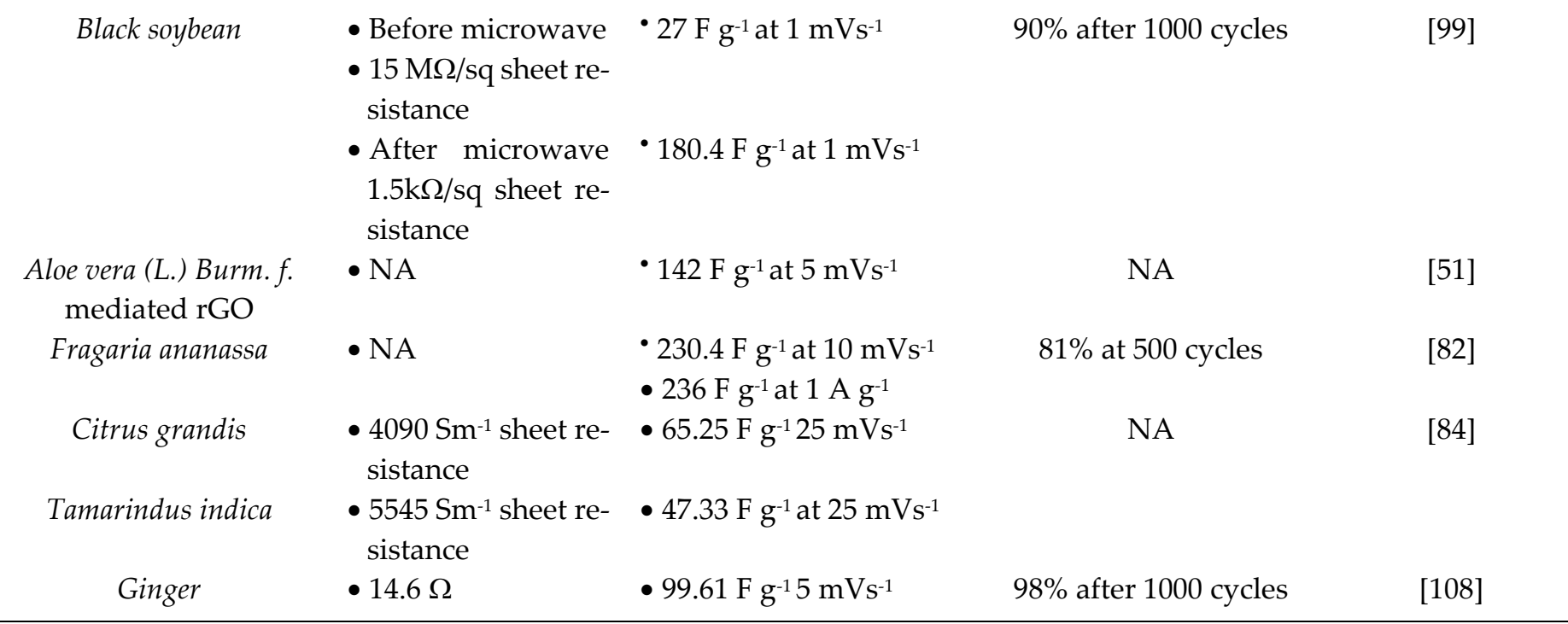

\subsection{Photocatalytic degradation}

There are several reports in the literature describing degradation applications of green synthesis rGO. Singh and colleagues (2018) synthesis rGO sheets (rG1-sugar cane juice and hydrazine hydrate) and disc structure using sugarcane juice as a reducing agent (rG2-sugarcane juice). The photocatalytic degradation of phenanthrene (PHE) using the synthesis rGO was further investigated under UV irradiation. PHE is one of the most prevalent polycyclic aromatic hydrocarbons (PAHs) in the environment, being produced continuously by a variety of sources. PAHs pose a serious threat to the environment and human health due to their hazardous and carcinogen nature. Pure PHE degrades at a rate of $5 \%$, whereas rG1 and rG2 degrades at a rate of $25 \%$ and $30 \%$, respectively. Due to the spherical disc-like structures, rG2 degrades PHE more efficiently than rG1. In comparison to the sheets structure, it contains a greater number of active catalytic sites for the interaction with PHE molecules [95].

Mahata et al. [54] demonstrated that rGO synthesis from Ocimum sanctum L. leaf extract is an efficient catalyst when used in combination with $\mathrm{NaBH}_{4}$ in water for the regioselective reduction of $\alpha, \beta$-unsaturated carbonyl compounds to their allylic alcohols. When the catalyst loading is increased from $10 \mathrm{mg}$ to $15 \mathrm{mg}$, the yield of the products increases by up to $92 \%$. However, increasing the catalyst concentration did not result in an increase in conversion rate, indicating that $15 \mathrm{mg}$ is the optimum catalyst loading. Another study conducted by the same group demonstrated that GO could be reduced using Anacardium occidentale Linn (Cashew) leaf extract (CLRG) as a bio-renewable catalyst. CLRG's catalytic activity was demonstrated to successfully reduce nitrobenzene to aniline with a yield of $94 \%$ in 4 hours. As a result, the prepared rGO catalyzed the electro-/chemical transformation of nitro to an amine group efficiently [52]. Suresh et al. demonstrated that rGO derived from Spinacia oleracea (leaf extract), Syzygium aromaticum (bud extract), and Cinnamomum zeylanicum (bark) completely degraded carcinogenic dye methylene blue (MB) and malachite green (MG) in the presence of $20 \mathrm{mg}$ rGO $[39,88,93]$.

Jin and co-workers (2018) reported the adsorptive capacity of biosynthesis rGO containing Eucalyptus leaf extract to that of other adsorbents, including activated carbon, graphite powder, and commercial graphene. The maximum adsorption capacity of various adsorbents was determined to be $\mathrm{rGO}>$ commercial graphene> activated carbon> graphite powder. Due to the rGO's high dispersibility, it adheres to the surface of biomolecules and increases the contact surface area with the MB [53]. As a green reducing agent, the prepared rGO from Aloe vera demonstrated remarkable dye removal ability, with a maximum efficiency of $98 \%$ achieved. The strong electrostatic interaction between the MB and rGO molecules, the strong $\pi-\pi$ interaction between the MB molecules, and the 
increased surface area of rGO all contributed to the increased adsorption efficiency. The recyclability of the synthesis rGO for up to five adsorption cycles without a significant loss of capability makes it an attractive candidate for industrial dye adsorbent material [115].

The adsorption capacity $\left(\mathrm{q}_{\mathrm{max}}\right.$ ) of synthesis rGO from Citrus hystrix peel extract on $\mathrm{MB}$ was determined to be $276.06 \mathrm{mg} / \mathrm{g}$ at room temperature [92]. Ghosh et al. [96] reported the photocatalytic activity of rGO synthesis using the bark extract of Alstonia scholaris (time duration 3 hour) towards $\mathrm{MB}$ and methyl orange (MO). It has been demonstrated that MB degrades at a rate of $95.29 \%$, whereas MO degrades at a rate of only $6 \%$. As a result, the rGO will be significantly more effective at removing cationic dye from wastewater than it will at removing anionic dye.

Parthipan et al. $[68,83]$ investigated the photocatalytic activity of rGO biosynthesis from Phyllanthus emblica fruit extracts (PErGO) and Murraya koenigii leaf extract (MKrGO) against $\mathrm{MB}, \mathrm{MO}$ and mixed $(\mathrm{MB}+\mathrm{MO})$ dye solutions when exposed to sunlight and $\mathrm{UV}$ light. PErGO treated with a mixed dye solution $(\mathrm{MB}+\mathrm{MO})$ and exposed to sunlight demonstrated degradation efficiencies of $92 \%$ and $91 \%$ for $\mathrm{MO}$ and MB dyes, respectively. Within 120 minutes of exposure to natural sunlight, the catalyst MKrGO was shown to degrade approximately $80 \%$ and $77 \%$ of $\mathrm{MO}$ and $\mathrm{MB}$ dyes, respectively. This observation implies that sunlight exposure is the best option for both dye molecules in the presence of the catalyst rGO. This catalyst's stability is maintained with only minor changes over the course of five degradation cycles.

Sugarcane bagasse extract was used to remove cadmium (Cd (II)), with an adsorption capacity of nearly $24.47 \mathrm{mg} / \mathrm{g}$. This demonstrates rGO's potential for removing heavy metals from wastewater [91]. Moosa and Jaafar (2017) demonstrated that rGO mediated by Camellia sinensis (black tea) leaf extract added to sand has a high removal efficiency for lead ions in aqueous solution. As the concentration of lead ions increases, the removal efficiency decreases due to lead ion saturation of adsorption sites [48]. Using a variety of experimental conditions, including $\mathrm{pH}$, temperature, adsorbent dose, and adsorbate concentration, it was demonstrated that rGO prepared from green tea extract (Camellia sinensis) successfully removed $\mathrm{Pb}$ (II) aqueous solution. The excellent removal efficiency of $\mathrm{Pb}$ (II) was determined to be $96.6 \%$ under operating conditions of $10 \mathrm{mg} / \mathrm{L} \mathrm{Pb}$ (II) and $0.4 \mathrm{~g} / \mathrm{L}$ rGO with a $\mathrm{pH} 4.5$ at $30^{\circ} \mathrm{C}$. The rGO is recyclable up to four times at the cost of only a partial adsorption capacity $\left(1^{\text {st }}\right.$ cycle- $97.4 \%$, $2^{\text {nd }}$ cycle- $96.7 \%$, $3^{\text {rd }}$ cycle- $87.8 \%$, and $4^{\text {th }}$ cycle- $80.0 \%$ ) [59].

It was demonstrated that the biologically synthesis rGO from Callistemon viminalis leaf extract has the potential to be used as a membrane filter for the removal of heavy metal ions from drinking water. The highest iron rejection rate of $95.77 \%$ was obtained when a greater amount of rGO (0.10 g) nanomaterials was used in the membrane. This rGO is used to remove heavy metals using a low-pressure driving force, and the increased hydrophilicity of the membrane results in a smoother water flux over a longer time period [72].

Table 5 summarized various catalytic studies utilizing rGO prepared using various plant extracts together with their concentration used, degradation time, percentage of removal and adsorption capacity.

Table 5. Summarized the catalytic activity of the synthesis rGO.

\begin{tabular}{|c|c|c|c|c|c|c|c|c|}
\hline $\begin{array}{c}\text { Scientific } \\
\text { name }\end{array}$ & $\begin{array}{l}\text { Dye } \\
\text { used }\end{array}$ & $\begin{array}{c}\text { Metal } \\
\text { ions }\end{array}$ & $\begin{array}{c}\text { Concentra- } \\
\text { tion }\end{array}$ & $\begin{array}{c}\text { Amount of } \\
\text { photo-cata- } \\
\text { lyst }\end{array}$ & $\begin{array}{l}\text { Time re- } \\
\text { quired for } \\
\text { degrada- } \\
\text { tion (min) }\end{array}$ & Feature & \% removal & $\begin{array}{l}\text { Ad- } \\
\text { sorp- } \\
\text { tion } \\
\text { ca- } \\
\text { pac- } \\
\text { ity }\end{array}$ \\
\hline
\end{tabular}




\begin{tabular}{|c|c|c|c|c|c|c|c|c|c|}
\hline $\begin{array}{l}\text { Spinacia } \\
\text { oleracea }\end{array}$ & $\begin{array}{l}\text { Meth- } \\
\text { ylene } \\
\text { blue } \\
\text { (MB) } \\
\text { Mala- } \\
\text { chite } \\
\text { green } \\
\text { (MG) }\end{array}$ & NA & $\begin{array}{l}\text { - } 100 \text { mL of } 5 \\
\text { ppm solu- } \\
\text { tion }\end{array}$ & - $20 \mathrm{mg}$ & $\begin{array}{l}\text { - } 60 \mathrm{~min} \\
\text { - } 40 \mathrm{~min}\end{array}$ & $\begin{array}{l}\text { - Dark } \\
\text { condi- } \\
\text { tion }\end{array}$ & - NA & NA & [39] \\
\hline $\begin{array}{l}\text { Syzyg- } \\
\text { ium aro- } \\
\text { maticum }\end{array}$ & $\begin{array}{l}\text { Meth- } \\
\text { ylene } \\
\text { blue } \\
(\mathrm{MB}) \\
\text { Mala- } \\
\text { chite } \\
\text { green } \\
\text { (MG) }\end{array}$ & NA & $\begin{array}{l}\text { - } 100 \mathrm{~mL} \text { of } 5 \\
\text { ppm solu- } \\
\text { tion }\end{array}$ & - $20 \mathrm{mg}$ & - $20 \mathrm{~min}$ & $\begin{array}{l}\text { - Dark } \\
\text { condi- } \\
\text { tion }\end{array}$ & - NA & NA & [88] \\
\hline $\begin{array}{c}\text { Cin- } \\
\text { namomum } \\
\text { zeylan- } \\
\text { icum }\end{array}$ & $\begin{array}{l}\text { Meth- } \\
\text { ylene } \\
\text { blue } \\
(\mathrm{MB}) \\
\text { Mala- } \\
\text { chite } \\
\text { green } \\
\text { (MG) }\end{array}$ & NA & $\begin{array}{l}\text { - } 100 \mathrm{~mL} \text { of } 5 \\
\text { ppm solu- } \\
\text { tion }\end{array}$ & - $20 \mathrm{mg}$ & - $40 \mathrm{~min}$ & $\begin{array}{l}\text { - Dark } \\
\text { condi- } \\
\text { tion }\end{array}$ & - NA & NA & [93] \\
\hline $\begin{array}{c}\text { Eucalyp- } \\
\text { tus }\end{array}$ & $\begin{array}{l}\text { Meth- } \\
\text { ylene } \\
\text { blue } \\
\text { (MB) }\end{array}$ & NA & $\begin{array}{l}\cdot 20 \mathrm{~mL} \text { of } 50 \\
\mathrm{mg} \mathrm{L}^{-1}\end{array}$ & $\bullet 0.02 \mathrm{~g}$ & - 10 & - NA & - NA & $\begin{array}{c}\sim 45 \\
\mathrm{mg} / \mathrm{g}\end{array}$ & [53] \\
\hline $\begin{array}{l}\text { Camellia } \\
\text { sinensis }\end{array}$ & NA & Lead & $\begin{array}{l}\text { - } 155.5 \text { ppm } \\
\text { • } 240.5 \text { ppm } \\
\text { - } 299 \text { ppm }\end{array}$ & - NA & - NA & - NA & $\begin{array}{l}\text { • } 99.9 \% \\
\text { • } 99.9 \% \\
\text { • } 92 \%\end{array}$ & & [48] \\
\hline $\begin{array}{c}\text { Sugarcane } \\
\text { bagasse }\end{array}$ & NA & $\begin{array}{l}\text { Cad- } \\
\text { mium }\end{array}$ & $\begin{array}{l}\text { - } 25 \mathrm{~mL} \text { of } \\
\mathrm{Cd} \text { (II) }(20 \\
\mathrm{mg} / \mathrm{L})\end{array}$ & - $12 \mathrm{mg}$ & - NA & - NA & - NA & $\begin{array}{l}24.47 \\
\mathrm{mg} / \mathrm{g}\end{array}$ & [91] \\
\hline Aloe vera & $\begin{array}{l}\text { Meth- } \\
\text { ylene } \\
\text { blue } \\
\text { (MB) }\end{array}$ & NA & $\begin{array}{l}\text { - } 125 \text { mL in } 4 \\
\text { ppm solu- } \\
\text { tion }\end{array}$ & - $20 \mathrm{mg}$ & - NA & - NA & • $98 \%$ & NA & [115] \\
\hline $\begin{array}{l}\text { Camellia } \\
\text { sinensis }\end{array}$ & NA & $\begin{array}{l}\text { Lead } \\
(\mathrm{Pb} \\
(\mathrm{II}))\end{array}$ & $\begin{array}{l}\text { - } 150 \mathrm{~mL} \text { of } \\
10 \mathrm{mg} / \mathrm{L} \text { so- } \\
\text { lution }\end{array}$ & $\bullet 0.4 \mathrm{~g} / \mathrm{L}$ & - NA & - NA & • $96.6 \%$ & & [59] \\
\hline $\begin{array}{l}\text { Citrus } \\
\text { hystrix }\end{array}$ & $\begin{array}{l}\text { Meth- } \\
\text { ylene } \\
\text { blue }\end{array}$ & NA & $\begin{array}{l}\text { - } 20 \mathrm{~mL} \text { of } 50 \\
\mathrm{mg} / \mathrm{L}\end{array}$ & - $5 \mathrm{mg}$ & - NA & - NA & - NA & 276.06 & [92] \\
\hline $\begin{array}{l}\text { Calliste- } \\
\text { mon vimi- } \\
\text { nalis }\end{array}$ & NA & Iron & - NA & $\bullet 0.10 \mathrm{~g}$ & - NA & - NA & • $95.77 \%$ & NA & [72] \\
\hline $\begin{array}{l}\text { Alstonia } \\
\text { scholaris }\end{array}$ & $\begin{array}{l}\text { Meth- } \\
\text { ylene } \\
\text { blue } \\
\text { (MB) }\end{array}$ & NA & $\begin{array}{l}\text { - } 50 \mathrm{~mL} \text { of } 12 \\
\mathrm{mg} \mathrm{L}^{-1}\end{array}$ & - $10 \mathrm{mg}$ & - NA & - NA & $\begin{array}{l}\text { - } 95.29 \% \\
\text { - } 6.03 \%\end{array}$ & NA & [96] \\
\hline
\end{tabular}


Me-

thyl

or-

ange

(MO)

Phyl- Mixed

lanthus dye

emblica (MB +

$\mathrm{MO})$

Mixed

dye

$(\mathrm{MB}+$

$\mathrm{MO})$
NA $\bullet 10 \mathrm{mg} / \mathrm{L}$<smiles>C1CCCCC1</smiles>

- $20 \mathrm{mg} / \mathrm{L}$

- 90 min

- Sun-

light

- $91 \%(\mathrm{MB})$

NA

expo-

- $92 \%(\mathrm{MO})$

sure

- UV

- $98 \% \mathrm{MB})$

- $49 \%$ (MO)

Meth-

NA

- $10 \mathrm{mg} / \mathrm{L}$

- $20 \mathrm{mg} / \mathrm{L}$

- 120 min

- Sun-

- $77 \%$

- NA

[68]

blue

Me-

expo-

sure

- $80 \%$

thyl

or-

ange

\subsection{Antioxidant}

Suresh and co-workers demonstrated that Spinacia oleracea (leaf extract), Syzygium aromaticum (bud extract), and Cinnamomum zeylanicum (bark) mediated rGO has scavenging activity against DPPH free radicals with IC 50 value of $1590 \mu \mathrm{g} / \mathrm{mL}, 1337 \mu \mathrm{g} / \mathrm{mL}, 2250$ $\mu \mathrm{g} / \mathrm{mL}$, respectively $[39,88,93]$.

\subsection{Sensors}

Haghighi and Tabrizi in 2013 demonstrated the use of Rosa damascene (rose water) as a reducing agent for GO reduction, and their ability to fabricate new types of sensors and biosensors was investigated using electrochemical measurements. Electrochemical impedance spectroscopy (EIS) measurements revealed that the rGO modified glassy carbon electrode (GCE) has a charge transfer resistance ( $\left.R_{\mathrm{ct}}\right)$ of $180 \Omega$ and a peak-to-peak separation of $96 \mathrm{mV}$ for the redox probe on $\mathrm{GCE} / \mathrm{rGO}$. By examining the electrochemical properties of catechol in phosphate buffer solution and nicotinamide adenine dinucleotide $(\mathrm{NADH})$ on a modified GCE/rGO electrode, the applicability of the prepared $\mathrm{rGO}$ for the fabrication of a new type of modified electrode was determined. GCE/rGO redox peaks for catechol had a formal potential of $140 \mathrm{mV} v s . \mathrm{Ag} / \mathrm{AgCl}$ and peak-to-peak separation of $97 \mathrm{mV}$, whereas NADH oxidation had a formal potential of $340 \mathrm{mV} v$ s. $\mathrm{Ag} / \mathrm{AgCl}$. Further studies on modified GCE/rGO electrodes with immobilized glucose oxidase (GOx) revealed redox peaks with a formal potential of $-412 \mathrm{mV} v s . \mathrm{Ag} / \mathrm{AgCl}$ and a $45 \mathrm{mV}$ peak-topeak separation. The results demonstrated that the synthesis rGO accelerated the electron transfer rate of a redox probe across the modified electrode interface. The electrocatalytic activity of GCE modified with rGO was excellent for catechol, NADH, and immobilized GOx [86].

Few years later, Chettri and colleagues demonstrated that 3D hedgehog-like nanostructures can self-assemble on the rGO surface without the use of external precursors. This enables the rGO to be used effectively as a template for the development of high-performance energy storage and biosensing devices [41]. We used rGO mediated by 
olive leaf to create a conductive indium tin oxide (ITO)/rGO modified electrode. Cyclic voltammetry was used to investigate the electrochemical properties of the ITO/rGO electrode and to demonstrate the response in the presence and absence of ascorbic acid. The ITO/rGO electrode had a larger cyclic voltammetry area (quasi-rectangular shape) and a higher specific capacitance $\left(275 \mathrm{~F} \mathrm{~g}^{-1}\right)$, indicating that it is a successful ascorbic acid sensor. As a result, this $\mathrm{rGO}$ is suitable for use as an electrode modifier in energy storage devices and as an AA sensor [44]. Ghosh and colleagues demonstrate how to reduce GO to greenly-rGO (GRGO) using a variety of green reagents, including starch, ascorbic acid, glucose, clove extract and mint extract. All GRGO samples were found to have slightly higher electrical conductivities. Cyclic voltammetry and impedance measurements on all the GRGO indicates that GRGO mediated mint leaf extract modified electrode has the highest current-voltage response and the lowest charge transfer resistance of $140 \Omega$ (Rct) [57].

\subsection{Nanocomposite}

Atarod et al. (2015) synthesis nanocomposite by biological reduction of GO, copper, and iron oxide $\left(\mathrm{Cu} / \mathrm{RGO} / \mathrm{Fe}_{3} \mathrm{O}_{4}\right)$ using Euphorbia wallichii leaf extract as a magnetically recoverable catalyst for the reduction of 4-nitrophenol (4-NP) to 4-aminophenol (4-AP) in the presence of $\mathrm{NaBH}_{4}$ and Rhodamine $\mathrm{B}(\mathrm{RhB})$ dye in water at room temperature. The $\mathrm{Cu} / \mathrm{RGO} / \mathrm{Fe}_{3} \mathrm{O}_{4}$ nanocomposite was found to be highly active and could be recycled without significant loss of activity for approximately six catalytic cycles [37]. rGO was synthesis from Melissa officinalis extract and combined with hydroxyapatite (HA) in various concentrations to form rGO-HA nanocomposite. The rGO-HA (1\%) composite was determined to be the optimal composition, with a 3.2-fold increase in strength compared to pure HA. The biocompatibility of rGO-HA nanocomposite at $1 \%$ and $0.5 \%$ concentrations was evaluated using NIH-3T3 fibroblast cells [45].

Elmike and colleagues in 2019, demonstrated the fabrication of rGO, zinc oxide nanoparticles $(\mathrm{ZnO})$, silver-zinc oxide nanoparticles (AgZnO) and rGOAgZnO nanocomposite using Stigmaphyllon ovatum leaf extract. Over 120 minutes of photocatalytic degradation of MB using the nanomaterials, the nanocomposite demonstrated the highest degradation efficiency of $68.1,62.7,61.7$, and $57.4 \%$ for the rGOAgZnO, $\mathrm{ZnO}, \mathrm{rGO}$ and AgZnO respectively [55]. Copper nanoparticles (Cu NPs) were deposited on rGO using Euphorbia cheiradenia leaf extract to form the $\mathrm{Cu} / \mathrm{rGO}$ nanocomposite, which demonstrated excellent degradation of 4-nitrophenol and hazardous dyes such as rhodamine B, methylene blue, methyl orange and congo red using $\mathrm{NaBH}_{4}$ at room temperature. $\mathrm{Cu} / \mathrm{rGO}$ nanocomposite has a five-cycle reusability potential without deteriorating its catalytic capability [56].

A bioinspired approach was used to synthesize a palladium anchored Thymbra spicata extract-modified graphene oxide nanohybrid material (Pd NPs/rGO-T. spicata). The nanohybrid material demonstrated excellent water dispersibility. The as-prepared material was demonstrated to be a heterogeneous catalyst for cyanating aryl halides $(X=I, B r$, $\mathrm{Cl}$ ) using potassium hexacyanoferrate (II) trihydrate as a relatively inexpensive source of cyanide. The nitriles were synthesis in a good condition with excellent yields over a range of reaction time. Catalyst can be recovered and reused up to eight times without significantly reducing their catalytic activity [62]. Khojasteh and colleagues investigated the reduction of GO to rGO using leaf extracts of Metha piperita and Tribulus terrestris, which both demonstrated moderate antioxidant activity in the DPPH assay $\left(\mathrm{IC}_{50}=28\right.$ and 33 ppm respectively). Mentha piperita extracts reduced GO more effectively than Tribulus terrestris extracts. Additional studies on the reducibility of Mentha piperita extract were conducted using the synthesize of $\mathrm{rGO} / \mathrm{Fe} 3 \mathrm{O} 4$ nanocomposite. Vibrating sample magnetometer analysis indicates that appropriate reduction of Fe ions and GO resulted in the formation of a $\mathrm{rGO} / \mathrm{Fe} 3 \mathrm{O} 4$ nanocomposite with superparamagnetic properties [58].

\section{Characterizations}


The reduction of GO to rGO with green reductants can be characterized using a variety of optical, structural, electrochemical, and thermal techniques to confirm the removal of oxygen moieties as listed in Figure 3. The optical properties were investigated using ultraviolet-visible spectroscopy, whereas the development of the crystalline structure was studied using X-ray diffraction. The functional groups were identified using Fourier transform infrared spectroscopy, and the electronic structures were deduced using Raman spectroscopy. The atomic composition and chemical covalent bond information were determined using X-ray photoelectron spectroscopy. The thickness of the sheet was determined using atomic force microscopy. To observe the morphology and examine the microstructures, field emission scanning electron microscopy and transmission electron microscopy were used. Thermal stability and thermal degradation properties were determined using thermogravimetric analysis. The average size and potential surface charge were determined using dynamic light scattering. Cyclic voltammetry was used to determine the electroactive surface area, and four-point probe resistivity was used to determine the sheet resistance.

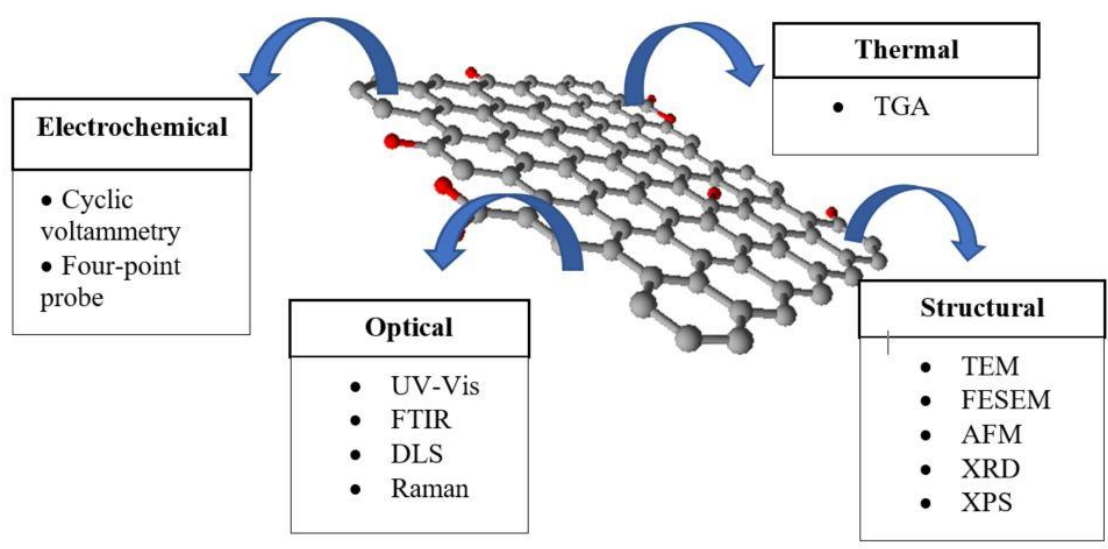

Figure 3. Characterization techniques used to verify the properties of successful rGO synthesis.

\section{Conclusion}

To summarize, there are an infinite number of plant species in nature, and countless of them have enormous potential for further exploration and investigation in order to produce green nanomaterials. The majority of plant parts such as leaves, roots, bark, stem, fruits and seeds are being used to synthesize GO and rGO, and this has proven to be a more sustainable, reliable, and feasible method than the chemical method. The critical advantages of using green reductants are that they are environmentally friendly, cost effective, simple to isolate the product, non-toxic, biocompatible, and readily available. In summary, rGO prepared via the green route has the potential to be extremely useful in a wide variety of applications and to open up new avenues for bulk production.

Author Contributions: Conceptualization, C.A.C.A., D.P., and E.L.A; writing-original draft preparation, D.P.; writing - review and editing, C.A.C.A. D.P, and E.L.A.; visualization, D.P.; supervision, C.A.C.A. All authors have read and agreed to the published version of the manuscript.

Funding: This research received no external funding.

Conflicts of Interest: The authors declare no conflict of interest.

\section{References}

1. Paton, K.R.; Varrla, E.; Backes, C.; Smith, R.J.; Khan, U.; O’Neill, A.; Boland, C.; Lotya, M.; Istrate, O.M.; King, P.; et al. Scalable production of large quantities of defect-free few-layer graphene by shear exfoliation in liquids. Nat. Mater. 2014, 13, 624-630, doi:10.1038/nmat3944. 
2. Novoselov, K.S.; Geim, A.K.; Morozov, S. V.; Jiang, D.; Zhang, Y.; Dubonos, S. V.; Grigorieva, I. V.; Firsov, A.A. Electric field in atomically thin carbon films. Science (80-. ). 2004, 306, 666-669, doi:10.1126/science.1102896.

3. Liu, Y.; Yu, D.; Zeng, C.; Miao, Z.; Dai, L. Biocompatible graphene oxide-based glucose biosensors. Langmuir 2010, 26, 6158-6160, doi:10.1021/la100886x.

4. Sun, X.; Liu, Z.; Welsher, K.; Robinson, J.T.; Goodwin, A.; Zaric, S.; Dai, H. Nano-graphene oxide for cellular imaging and drug delivery. Nano Res. 2008, 1, 203-212, doi:10.1007/s12274-008-8021-8.

5. Guo, C.X.; Wang, M.; Chen, T.; Lou, X.W.; Li, C.M. A hierarchically nanostructured composite of MnO2 / conjugated polymer / graphene for high-performance lithium ion batteries. Adv. Energy Mater. 2011, 1, 736-741, doi:10.1002/aenm.201100223.

6. Jo, G.; Choe, M.; Lee, S.; Park, W. The application of graphene as electrodes in electrical and optical devices. Nanotechnology 2012, 23, 112001, doi:10.1088/0957-4484/23/11/112001.

7. Hu, W.; Peng, C.; Luo, W.; Lv, M.; Li, X.; Li, D.; Huang, Q.; Fan, C. Graphene-based antibacterial paper. ACS Nano 2010, 4, 4317-4323.

8. Kumar, S.; Ojha, A.K.; Patrice, D.; Yadav, B.S.; Materny, A. One step in-situ synthesis of CeO2 nanoparticles grown on reduced graphene oxide as an excellent fluorescent and photocatalyst material under sunlight irradiation. Phys. Chem. Chem. Phys. 2016, 18, 11157-11167, doi:10.1039/C5CP04457J.

9. Ghosh, T.K.; Gope, S.; Rana, D.; Roy, I.; Sarkar, G.; Sadhukhan, S.; Bhattacharya, A.; Pramanik, K.; Chattopadhyay, S.; Chakraborty, M.; et al. Physical and electrical characterization of reduced graphene oxide synthesized adopting green route. Bull. Mater. Sci. 2016, 39, 543-550, doi:10.1007/s12034-016-1156-4.

10. Romero, A.; Lavin-Lopez, M.P.; Sanchez-Silva, L.; Valverde, J.L.; Paton-Carrero, A. Comparative study of different scalable routes to synthesize graphene oxide and reduced graphene oxide. Mater. Chem. Phys. 2018, 203, 284-292, doi:10.1016/j.matchemphys.2017.10.013.

11. Zaaba, N.I.; Foo, K.L.; Hashim, U.; Tan, S.J.; Liu, W.W.; Voon, C.H. Synthesis of Graphene Oxide using Modified Hummers Method: Solvent Influence. Procedia Eng. 2017, 184, 469-477, doi:10.1016/j.proeng.2017.04.118.

12. B.C. Brodie On the Atomic Weight of Graphite Author ( s ): B . C . Brodie Source : Philosophical Transactions of the Royal Society of London, Vol . 149 ( 1859 ), pp . 249- Published by: Royal Society Stable URL: http://www.jstor.org/stable/108699 Accessed : 27-04-. Philos. Trans. R. Scociety London 1859, 149, $249-259$.

13. Staudenmaier, L. Method for the preparation of the graphite acid. Eur. J. Inorg. Chem. 1898, 31, $1481-1487$.

14. Hummers, W.S.; Offeman, R.E. Preparation of Graphitic Oxide. J. Am. Chem. Soc. 1958, 80, 1339.

15. Marcano, D.C.; Kosynkin, D. V; Berlin, J.M.; Sinitskii, A.; Sun, Z.; Slesarev, A.; Alemany, L.B.; Lu, W.; Tour, J.M. Improved synthesis of graphene oxide. ACS Nano 2010, 4, 4806-4814.

16. Smith, A.T.; LaChance, A.M.; Zeng, S.; Liu, B.; Sun, L. Synthesis, properties, and applications of graphene oxide/reduced graphene oxide and their nanocomposites. Nano Mater. Sci. 2019, 1, 31-47, 
doi:10.1016/j.nanoms.2019.02.004.

17. Agarwal, V.; Zetterlund, P.B. Strategies for reduction of graphene oxide - A comprehensive review. Chem. Eng. J. 2021, 405, doi:10.1016/j.cej.2020.127018.

18. Sharma, N.; Sharma, V.; Jain, Y.; Kumari, M.; Gupta, R.; Sharma, S.K.; Sachdev, K. Synthesis and Characterization of Graphene Oxide (GO) and Reduced Graphene Oxide (rGO) for Gas Sensing Application. Macromol. Symp. 2017, 376, 1-5, doi:10.1002/masy.201700006.

19. Tran, D.N.H.; Kabiri, S.; Losic, D. A green approach for the reduction of graphene oxide nanosheets using nonaromatic amino acids. Carbon N. Y. 2014, 76, 193-202, doi:10.1016/j.carbon.2014.04.067.

20. Azizighannad, S.; Mitra, S. Stepwise reduction of Graphene Oxide (GO) and its effects on chemical and colloidal properties. Sci. Rep. 2018, doi:10.1038/s41598-018-28353-6.

21. Stankovich, S.; Dikin, D.A.; Piner, R.D.; Kohlhaas, K.A.; Kleinhammes, A.; Jia, Y.; Wu, Y.; Nguyen, S.B.T.; Ruoff, R.S. Synthesis of graphene-based nanosheets via chemical reduction of exfoliated graphite oxide. Carbon N. Y. 2007, 45, 1558-1565, doi:10.1016/j.carbon.2007.02.034.

22. Wang, G.; Yang, J.; Park, J.; Gou, X.; Wang, B.; Liu, H.; Yao, J. Facile Synthesis and characterization of graphene nanosheets. J. Phys. Chem. C 2008, 112, 8192-8195.

23. Si, Y.; Samulski, E.T. Synthesis of Water Soluble Graphene 2008. Nano Lett. 2008, 8, 1679-1682.

24. Chua, C.K.; Pumera, M. Chemical reduction of graphene oxide: A synthetic chemistry viewpoint. Chem. Soc. Rev. 2014, 43, 291-312, doi:10.1039/c3cs60303b.

25. Mei, X.; Ouyang, J. Ultrasonication-assisted ultrafast reduction of graphene oxide by zinc powder at room temperature. Carbon N. Y. 2011, 49, 5389-5397, doi:10.1016/j.carbon.2011.08.019.

26. Agharkar, M.; Kochrekar, S.; Hidouri, S.; Azeez, M.A. Trends in green reduction of graphene oxides, issues and challenges: A review. Mater. Res. Bull. 2014, 59, 323-328, doi:10.1016/j.materresbull.2014.07.051.

27. Medha, G.; Sharmila, C.; Anil, G. Green Synthesis and Characterization of Nanocrystalline Graphene Oxide. Int. Res. J. Sci. Eng. 2017, 29-34.

28. Shubha, P.; Namratha, K.; Aparna, H.S.; Ashok, N.R.; Mustak, M.S.; Chatterjee, J.; Byrappa, K. Facile green reduction of graphene oxide using Ocimum sanctum hydroalcoholic extract and evaluation of its cellular toxicity. Mater. Chem. Phys. 2017, 198, 66-72, doi:10.1016/j.matchemphys.2017.05.062.

29. Rice-Evans, C.A.; Miller, N.J.; Paganga, G. Structure-antioxidant activity relationships of flavonoids and phenolic acids. Free Radic. Biol. Med. 1996, 20, 933-956.

30. Thakur, S.; Karak, N. Green reduction of graphene oxide by aqueous phytoextracts. Carbon N. Y. 2012, 50, 53315339, doi:10.1016/j.carbon.2012.07.023.

31. Gurunathan, S.; Han, J.W.; Eppakayala, V.; Dayem, A.A.; Kwon, D.; Kim, J. Biocompatibility effects of 
biologically synthesized graphene in primary mouse embryonic fibroblast cells. Nanoscale Res. Lett. 2013, 8, 1-13.

32. Gurunathan, S.; Han, J.W.; Park, J.H.; Eppakayala, V.; Kim, J.H. Ginkgo biloba : a natural reducing agent for the synthesis of cytocompatible graphene. Int. J. Nanomedicine 2014, 9, 363-377.

33. Lalitha, M.J.F.P. Phyto-reduction of graphene oxide using the aqueous extract of Eichhornia crassipes ( Mart .) Solms. Int. Nano Lett. 2014, 4, 103-108, doi:10.1007/s40089-014-0125-4.

34. Khan, M.; Al-Marri, A.H.; Khan, M.; Mohri, N.; Adil, S.F.; Al-Warthan, A.; Siddiqui, M.R.H.; Alkhathlan, H.Z.; Berger, R.; Tremel, W.; et al. Pulicaria glutinosa plant extract: A green and eco-friendly reducing agent for the preparation of highly reduced graphene oxide. RSC Adv. 2014, 4, 24119-24125, doi:10.1039/c4ra01296h.

35. Lee, G.; Kim, B.S. Biological reduction of graphene oxide using plant leaf extracts. Biotechnol. Prog. 2014, 30, 463469, doi:10.1002/btpr.1862.

36. Kumar, G.G.; Babu, K.J.; Nahm, K.S.; Hwang, Y.J. A facile one-pot green synthesis of reduced graphene oxide and its composites for non- enzymatic hydrogen peroxide sensor applications. RSC Adv. 2014, 4, 7944-7951, doi:10.1039/c3ra45596c.

37. Atarod, M.; Nasrollahzadeh, M.; Sajadi, S.M. Green synthesis of a Cu/reduced graphene oxide/ Fe3O4 nanocomposite using Euphorbia wallichii leaf extract and its application as a recyclable and heterogeneous catalyst for the reduction of 4- nitrophenol and rhodamine B. RSC Adv. 2015, 5, 91532-91543, doi:10.1039/C5RA17269A.

38. Jana, M.; Saha, S.; Samanta, P.; Chandra, N.; Hee, J.; Kuila, T. Investigation of the capacitive performance of tobacco solution reduced graphene oxide. Mater. Chem. Phys. 2015, 151, 72-80, doi:10.1016/j.matchemphys.2014.11.037.

39. Suresh, D.; Nethravathi, P.C.; Udayabhanu; Nagabhushana, H.; Sharma, S.C. Spinach assisted green reduction of graphene oxide and its antioxidant and dye absorption properties. Ceram. Int. 2015, 41, 4810-4813, doi:10.1016/j.ceramint.2014.12.036.

40. Chamoli, P.; Sharma, R.; Das, K.; Kar, K.K. Mangifera indica, Ficus religiosa and Polyalthia longifolia leaf extractassisted green synthesis of graphene for transparent highly conductive film. RSC Adv. 2016, 6, 96355-96366, doi:10.1039/C6RA19111H.

41. Chettri, P.; Vendamani, V.S.; Tripathi, A.; Pathak, A.P.; Tiwari, A. Self assembly of functionalised graphene nanostructures by one step reduction of graphene oxide using aqueous extract of Artemisia vulgaris. Appl. Surf. Sci. 2016, 362, 221-229, doi:10.1016/j.apsusc.2015.11.231.

42. Sadhukhan, S.; Kumar, T.; Rana, D.; Roy, I. Studies on synthesis of reduced graphene oxide ( RGO ) via green route and its electrical property. Mater. Res. Bull. 2016, 79, 41-51, doi:10.1016/j.materresbull.2016.02.039.

43. Xing, F.Y.; Guan, L.L.; Li, Y.L.; Jia, C.J. Biosynthesis of reduced graphene oxide nanosheets and their in vitro cytotoxicity against cardiac cell lines of Catla catla. Environ. Toxicol. Pharmacol. 2016, 48, 110-115, doi:10.1016/j.etap.2016.09.022. 
44. Baioun, A.; Kellawi, H.; Falah, A. A modified electrode by a facile green preparation of reduced graphene oxide utilizing olive leaves extract. Carbon Lett. 2017, 24, 47-54, doi:10.5714/CL.2017.24.047.

45. Elif, Ö.; Belma, Ö.; Ilkay, Ş. Production of biologically safe and mechanically improved reduced graphene oxide/hydroxyapatite composites. Mater. Res. Express 2017, 4, 015601, doi:10.1088/2053-1591/aa5464.

46. Chandu, B.; Sai, V.; Mosali, S.; Mullamuri, B.; Bollikolla, H.B. A facile green reduction of graphene oxide using Annona squamosa leaf extract. Carbon Lett. 2017, 21, 74-80, doi:10.5714/CL.2017.21.074.

47. Li, C.; Zhuang, Z.; Jin, X.; Chen, Z. A facile and green preparation of reduced graphene oxide using Eucalyptus leaf extract. Appl. Surf. Sci. 2017, 422, 469-474, doi:10.1016/j.apsusc.2017.06.032.

48. Moosa, A.A.; Jaafar, J.N. Green reduction of graphene oxide using tea leaves extract with applications to lead ions removal from water. Nanosci. Nanotechnol. 2017, 7, 38-47, doi:10.5923/j.nn.20170702.03.

49. Zhu, X.; Xu, X.; Liu, F.; Jin, J.; Liu, L.; Zhi, Y.; Chen, Z.; Zhou, Z.; Yu, J. Green synthesis of graphene nanosheets and their in vitro cytotoxicity against human prostate cancer ( DU 145 ) cell lines. Nanomater. Nanotechnol. 2017, 7, 1-7, doi:10.1177/1847980417702794.

50. Bhattacharya, G.; Sas, S.; Wadhwa, S.; Mathur, A.; McLaughlin, J.; Roy, S.S. Aloe vera assisted facile green synthesis of reduced graphene oxide for electrochemical and dye removal applications. RSC Adv. 2017, 7, 2668026688, doi:10.1039/c7ra02828h.

51. Ramanathan, S.; Elanthamilan, E.; Obadiah, A.; Durairaj, A.; Merlin, J.P.; Ramasundaram, S.; Vasanthkumar, S. Aloe vera ( L .) Burm . f . extract reduced graphene oxide for supercapacitor application. J. Mater. Sci. Mater. Electron. 2017, 28, 16648-16657, doi:10.1007/s10854-017-7576-0.

52. Mahata, S.; Sahu, A.; Shukla, P.; Rai, A.; Singh, M.; Rai, V.K. Bio-inspired unprecedented synthesis of reduced graphene oxide: catalytic probe for electro-/chemical reduction of nitro group in aqueous medium. New J. Chem. 2018, 42, 2067-2073, doi:10.1039/C7NJ04732K.

53. Jin, X.; Li, N.; Weng, X.; Li, C.; Chen, Z. Green reduction of graphene oxide using eucalyptus leaf extract and its application to remove dye. Chemosphere 2018, 208, 417-424, doi:10.1016/j.chemosphere.2018.05.199.

54. Mahata, S.; Sahu, A.; Shukla, P.; Rai, A.; Singh, M.; Rai, V.K. The novel and efficient reduction of graphene oxide using Ocimum sanctum L . leaf extract as an alternative renewable bio-resource. New J. Chem. 2018, 42, 1994519952, doi:10.1039/C8NJ04086A.

55. Elemike, E.E.; Onwudiwe, D.C.; Wei, L.; Lou, C.; Zhao, Z. Synthesis of nanostructured ZnO, AgZnO and the composites with reduced graphene oxide (rGO-AgZnO) using leaf extract of Stigmaphyllon ovatum. J. Environ. Chem. Eng. 2019, 7, 103190, doi:10.1016/j.jece.2019.103190.

56. Fahiminia, M.; Shamabadi, N.S.; Nasrollahzadeh, M.; Mohammad Sajadi, S. Phytosynthesis of Cu/rGO using Euphorbia cheiradenia Boiss extract and study of its ability in the reduction of organic dyes and 4-nitrophenol in aqueous medium. IET Nanobiotechnology 2019, 13, 202-213, doi:10.1049/iet-nbt.2018.5175. 
57. Ghosh, T.K.; Sadhukhan, S.; Rana, D.; Bhattacharyya, A.; Chattopadhyay, D.; Chakraborty, M. ku. Green approaches to synthesize reduced graphene oxide and assessment of its electrical properties. Nano-Structures and Nano-Objects 2019, 19, 100362, doi:10.1016/j.nanoso.2019.100362.

58. Khojasteh, H.; Safajou, H.; Mortazavi-Derazkola, S.; Salavati-Niasari, M.; Heydaryan, K.; Yazdani, M. Economic procedure for facile and eco-friendly reduction of graphene oxide by plant extracts; a comparison and property investigation. J. Clean. Prod. 2019, 229, 1139-1147, doi:10.1016/j.jclepro.2019.04.350.

59. Lin, Z.; Weng, X.; Ma, L.; Sarkar, B.; Chen, Z. Mechanistic insights into Pb(II) removal from aqueous solution by green reduced graphene oxide. J. Colloid Interface Sci. 2019, 550, 1-9, doi:10.1016/j.jcis.2019.04.078.

60. Mahmudzadeh, M.; Yari, H.; Ramezanzadeh, B.; Mahdavian, M. Highly potent radical scavenging-anti-oxidant activity of biologically reduced graphene oxide using Nettle extract as a green bio-genic amines- based reductants source instead of hazardous hydrazine hydrate. J. Hazard. Mater. 2019, 371, 609-624, doi:10.1016/j.jhazmat.2019.03.046.

61. Lin, S.; Ruan, J.; Wang, S. Biosynthesized of reduced graphene oxide nanosheets and its loading with paclitaxel for their anti cancer effect for treatment of lung cancer. J. Photochem. Photobiol. B Biol. 2019, 191, 13-17, doi:10.1016/j.jphotobiol.2018.11.015.

62. Veisi, H.; Tamoradi, T.; Karmakar, B.; Mohammadi, P.; Hemmati, S. In situ biogenic synthesis of Pd nanoparticles over reduced graphene oxide by using a plant extract (Thymbra spicata) and its catalytic evaluation towards cyanation of aryl halides. Mater. Sci. Eng. C 2019, 104, 109919, doi:10.1016/j.msec.2019.109919.

63. Lingaraju, K.; Raja Naika, H.; Nagaraju, G.; Nagabhushana, H. Biocompatible synthesis of reduced graphene oxide from Euphorbia heterophylla (L.) and their in-vitro cytotoxicity against human cancer cell lines. Biotechnol. Reports 2019, 24, e00376, doi:10.1016/j.btre.2019.e00376.

64. Wang, C.; Wang, X.; Chen, Y.; Fang, Z. In-vitro photothermal therapy using plant extract polyphenols functionalized graphene sheets for treatment of lung cancer. J. Photochem. Photobiol. B Biol. 2020, 204, 111587, doi:10.1016/j.jphotobiol.2019.111587.

65. Amir Faiz, M.S.; Che Azurahanim, C.A.; Raba'ah, S.A.; Ruzniza, M.Z. Low cost and green approach in the reduction of graphene oxide (GO) using palm oil leaves extract for potential in industrial applications. Results Phys. 2020, 16, 102954, doi:https://doi.org/10.1016/j.rinp.2020.102954.

66. Sabayan, B.; Goudarzian, N.; Moslemin, M.H.; Mohebat, R. Green synthesis and high efficacy method for reduced graphene oxide by Zataria multiflora extract. J. Environ. Treat. Tech. 2020, 8, 488-496.

67. Olorunkosebi, A.A.; Eleruja, M.A.; Adedeji, A.V.; Olofinjana, B.; Fasakin, O.; Omotoso, E.; Oyedotun, K.O.; Ajayi, E.O.B.; Manyala, N. Optimization of graphene oxide through various Hummers' methods and comparative reduction using green approach. Diam. Relat. Mater. 2021, 117, 108456, doi:10.1016/j.diamond.2021.108456.

68. Parthipan, P.; Al-Dosary, M.A.; Al-Ghamdi, A.A.; Subramania, A. Eco-friendly synthesis of reduced graphene oxide as sustainable photocatalyst for removal of hazardous organic dyes. J. King Saud Univ. - Sci. 2021, 33, 101438, doi:10.1016/j.jksus.2021.101438. 
69. Andrianiaina, H.; Razanamahandry, L.C.; Sackey, J.; Ndimba, R.; Khamlich, S.; Maaza, M. Synthesis of graphene sheets from graphite flake mediated with extracts of various indigenous plants from Madagascar. Mater. Today Proc. 2021, 36, 553-558, doi:10.1016/j.matpr.2020.05.327.

70. Punniyakotti, P.; Aruliah, R.; Angaiah, S. Facile synthesis of reduced graphene oxide using Acalypha indica and Raphanus sativus extracts and their in vitro cytotoxicity activity against human breast (MCF-7) and lung (A549) cancer cell lines. 3 Biotech 2021, 11, 1-11, doi:10.1007/s13205-021-02689-9.

71. Qi, J.; Zhang, S.; Xie, C.; Liu, Q.; Yang, S. Fabrication of Erythrina senegalensis leaf extract mediated reduced graphene oxide for cardiac repair applications in the nursing care. Inorg. Nano-Metal Chem. 2021, 51, 143-149, doi:10.1080/24701556.2020.1769663.

72. Jha, P.K.; Khongnakorn, W.; Chawenjkigwanich, C.; Chowdhury, M.S.; Techato, K. Eco-friendly reduced graphene oxide nanofilter preparation and application for iron removal. Separations 2021, 8, 2-17, doi:10.3390/separations8050068.

73. Kartick, B.; Srivastava, S.K.; Srivastava, I. Green synthesis of graphene. J. Nanosci. Nanotechnol. 2013, 13, 43204324, doi:10.1166/jnn.2013.7461.

74. Tavakoli, F.; Salavati-Niasari, M.; Badiei, A.; Mohandes, F. Green synthesis and characterization of graphene nanosheets. Mater. Res. Bull. 2015, 63, 51-57, doi:10.1016/j.materresbull.2014.11.045.

75. Upadhyay, R.K.; Soin, N.; Bhattacharya, G.; Saha, S.; Barman, A.; Roy, S.S. Grape extract assisted green synthesis of reduced graphene oxide for water treatment application. Mater. Lett. 2015, 160, 355-358, doi:10.1016/j.matlet.2015.07.144.

76. Maddinedi, S.B.; Mandal, B.K. Biofabrication of Reduced Graphene Oxide Nanosheets Using Terminalia bellirica Fruit Extract. Curr. Nanosci. 2016, 12, 94-102.

77. Hou, D.; Liu, Q.; Cheng, H.; Li, K. Graphene Synthesis via Chemical Reduction of Graphene Oxide Using Lemon Extract. J. Nanosci. Nanotechnol. 2017, 17, 6518-6523, doi:10.1166/jnn.2017.14426.

78. Hou, D.; Liu, Q.; Cheng, H.; Zhang, H.; Wang, S. Green reduction of graphene oxide via Lycium barbarum extract. J. Solid State Chem. 2017, 246, 351-356, doi:10.1016/j.jssc.2016.12.008.

79. Ansari, M.Z.; Siddiqui, W.A. Deoxygenation of graphene oxide using biocompatible reducing agent Ficus carica (dried ripe fig). J. Nanostructure Chem. 2018, 8, 431-440, doi:10.1007/s40097-018-0283-4.

80. Ansari, M.Z.; Lone, M.N.; Sajid, S.; Siddiqui, W.A. Novel Green Synthesis of Graphene Layers using Zante Currants and Graphene Oxide. Orient. J. Chem. 2018, 34, 2832-2837, doi:10.13005/ojc/340621.

81. Ansari, M.Z.; Rahul; Siddiqui, W.A. Novel and green synthesis of chemically reduced graphene sheets using Phyllanthus emblica (Indian Gooseberry) and its photovoltaic activity. Mater. Res. Express 2019, 6, 055027.

82. Raja, A.; Rajasekaran, P.; Selvakumar, K.; Arivanandhan, M.; Asath Bahadur, S.; Swaminathan, M. Green approach to the preparation of reduced graphene oxide for photocatalytic and supercapacitor application. Optik 
(Stuttg). 2019, 190, 21-27, doi:10.1016/j.ijleo.2019.05.052.

83. Parthipan, P.; Cheng, L.; Rajasekar, A.; Govarthanan, M.; Subramania, A. Biologically reduced graphene oxide as a green and easily available photocatalyst for degradation of organic dyes. Environ. Res. 2021, 196, 110983, doi:10.1016/j.envres.2021.110983.

84. Panicker, N.J.; Sahu, P.P. Green reduction of graphene oxide using phytochemicals extracted from Pomelo Grandis and Tamarindus indica and its supercapacitor applications. J. Mater. Sci. Mater. Electron. 2021, 32, 1526515278, doi:10.1007/s10854-021-06077-0.

85. Smina, C.S.; Lalitha, P.; Sharma, S.C.; Nagabhushana, H. Screening of anti-cancer activity of reduced graphene oxide biogenically synthesized against human breast cancer MCF-7 cell lines. Appl. Nanosci. 2021, 11, 1093-1105, doi:10.1007/s13204-021-01696-9.

86. Haghighi, B.; Tabrizi, M.A. Green-synthesis of reduced graphene oxide nanosheets using rose water and a survey on their characteristics and applications. RSC Adv. 2013, 3, 13365-13371.

87. Chu, H.; Lee, C.; Tai, N. Green reduction of graphene oxide by Hibiscus sabdariffa L . to fabricate flexible graphene electrode. Carbon N. Y. 2014, 80, 725-733, doi:10.1016/j.carbon.2014.09.019.

88. Suresh, D.; Udayabhanu; Nagabhushana, H.; Sharma, S.C. Clove extract mediated facile green reduction of graphene oxide, its dye elimination and antioxidant properties. Mater. Lett. 2015, 142, 4-6, doi:10.1016/j.matlet.2014.11.073.

89. Hou, D.; Liu, Q.; Cheng, H.; Li, K.; Wang, D.; Zhang, H. Chrysanthemum extract assisted green reduction of graphene oxide. Mater. Chem. Phys. 2016, 183, 76-82, doi:10.1016/j.matchemphys.2016.08.004.

90. Shahane, S.; Sidhaye, D. Facile biosynthesis of reduced graphene oxide nanostructures via reduction by tagetes erecta (marigold flower) plant extract. Int. J. Mod. Phys. B 2018, 32, 1840068, doi:10.1142/S0217979218400684.

91. Li, B.; Jin, X.; Lin, J.; Chen, Z. Green reduction of graphene oxide by sugarcane bagasse extract and its application for the removal of cadmium in aqueous solution. J. Clean. Prod. 2018, 189, 128-134, doi:10.1016/j.jclepro.2018.04.018.

92. Wijaya, R.; Andersan, G.; Permatasari Santoso, S.; Irawaty, W. Green Reduction of Graphene Oxide using Kaffir Lime Peel Extract (Citrus hystrix) and Its Application as Adsorbent for Methylene Blue. Sci. Rep. 2020, 10, 1-9, doi:10.1038/s41598-020-57433-9.

93. Suresh, D.; Udayabhanu; Kumar, P.M..; Nagabhushana, H.; Sharma, S.C. Cinnamon supported facile green reduction of graphene oxide, its dye elimination and antioxidant activities. Mater. Lett. 2015, 151, 93-95, doi:10.1016/j.matlet.2015.03.035.

94. Han, W.; Niu, W.; Sun, B.; Shi, G.; Cui, X. Biofabrication of polyphenols stabilized reduced graphene oxide and its anti-tuberculosis activity. J. Photochem. Photobiol. BBiology 2016, 165, 305-309, doi:10.1016/j.jphotobiol.2016.10.032. 
95. Singh, A.; Ahmed, B.; Singh, A.; Ojha, A.K. Photodegradation of phenanthrene catalyzed by rGO sheets and disk like structures synthesized using sugar cane juice as a reducing agent. Spectrochim. Acta - Part A Mol. Biomol. Spectrosc. 2018, 204, 603-610, doi:10.1016/j.saa.2018.06.086.

96. Ghosh, S.; Das, P.; Baskey, M. Plant extract assisted synthesis of reduced graphene oxide sheet and the photocatalytic performances on cationic and anionic dyes to decontaminate wastewater. Adv. Nat. Sci. Nanosci. Nanotechnol. 2021, 12, 015008, doi:10.1088/2043-6254/abde41.

97. Jana, M.; Saha, S.; Khanra, P.; Chandra, N.; Kumar, S.; Kuila, T.; Hee, J. Bio-reduction of graphene oxide using drained water from soaked mung beans ( Phaseolus aureus L .) and its application as energy storage electrode material. Mater. Sci. Eng. B 2014, 186, 33-40, doi:10.1016/j.mseb.2014.03.004.

98. Maddinedi, S.B.; Mandal, B.K.; Vankayala, R.; Kalluru, P.; Pamanji, S.R. Bioinspired reduced graphene oxide nanosheets using Terminalia chebula seeds extract. Spectrochim. Acta - Part A Mol. Biomol. Spectrosc. 2015, 145, 117-124, doi:10.1016/j.saa.2015.02.037.

99. Chu, H.; Lee, C.; Tai, N. Green preparation using black soybeans extract for graphene-based porous electrodes and their applications in supercapacitors. J. Power Sources 2016, 322, 31-39, doi:10.1016/j.jpowsour.2016.04.068.

100. Yaragalla, S.; Rajendran, R.; Jose, J.; Almaadeed, M.A.; Kalarikkal, N.; Thomas, S. Preparation and characterization of green graphene using grape seed extract for bioapplications. Mater. Sci. Eng. C 2016, 65, 345353, doi:10.1016/j.msec.2016.04.050.

101. Tayade, U.S.; Borse, A.U.; Meshram, J.S. Green reduction of graphene oxide and its applications in band gap calculation and antioxidant activity. Green Mater. 2019, 7, 143-155, doi:10.1680/jgrma.18.00060.

102. Kuila, T.; Bose, S.; Khanra, P.; Mishra, A.K.; Kim, N.H.; Lee, J.H. A green approach for the reduction of graphene oxide by wild carrot root. Carbon N. Y. 2012, 50, 914-921, doi:10.1016/j.carbon.2011.09.053.

103. Akhavan, O.; Ghaderi, E.; Abouei, E.; Hatamie, S.; Ghasemi, E. Accelerated differentiation of neural stem cells into neurons on ginseng-reduced graphene oxide sheets. Carbon N. Y. 2013, 66, 395-406, doi:10.1016/j.carbon.2013.09.015.

104. Vusa, C.S.R.; Berchmans, S.; Alwarappan, S. Facile and green synthesis of graphene. RSC Adv. 2014, 4, 2247022475, doi:10.1039/c4ra01718h.

105. Khan, M.; Al-Marri, A.H.; Khan, M.; Shaik, M.R.; Mohri, N.; Adil, S.F.; Kuniyil, M.; Alkhathlan, H.Z.; Al-Warthan, A.; Tremel, W.; et al. Green approach for the effective reduction of graphene oxide using Salvadora persica L. root (Miswak) extract. Nanoscale Res. Lett. 2015, 10, 1-9, doi:10.1186/s11671-015-0987-z.

106. Thongpool, V.; Phunpheok, A.; Piriyawong, V.; Limsuwan, S. Green Approach for the Reduction of Graphene Oxide by Thai Shallot. Key Eng. Mater. 2016, 675-676, 696-699, doi:10.4028/www.scientific.net/KEM.675-676.696.

107. Khanam, P.N.; Hasan, A. Biosynthesis and characterization of graphene by using non-toxic reducing agent from Allium Cepa extract: Anti-bacterial properties. Int. J. Biol. Macromol. 2019, 126, 151-158, doi:10.1016/j.ijbiomac.2018.12.213. 
108. Rai, S.; Bhujel, R.; Biswas, J.; Swain, B.P. Biocompatible synthesis of rGO from ginger extract as a green reducing agent and its supercapacitor application. Bull. Mater. Sci. 2021, 44, doi:10.1007/s12034-020-02318-w.

109. Asiq Rahman, O.S.; Chellasamy, V.; Ponpandian, N.; Amirthapandian, S.; Panigrahi, B.K.; Thangadurai, P. A facile green synthesis of reduced graphene oxide by using pollen grains of Peltophorum pterocarpum and study of its electrochemical behavior. RSC Adv. 2014, 4, 56910-56917, doi:10.1039/c4ra06203e.

110. Paredes, J.I.; Villar-Rodil, S.; Martínez-Alonso, A.; Tascón, J.M.D. Graphene oxide dispersions in organic solvents. Langmuir 2008, 24, 10560-10564, doi:10.1021/la801744a.

111. Zhang, T.Y.; Zhang, D. Aqueous colloids of graphene oxide nanosheets by exfoliation of graphite oxide without ultrasonication. Bull. Mater. Sci. 2011, 34, 25-28, doi:10.1007/s12034-011-0048-x.

112. Aunkor, M.T.H.; Mahbubul, I.M.; Saidur, R.; Metselaar, H.S.C. The green reduction of graphene oxide. Rsc Adv. 2016, 6, 27807-27828.

113. Bosch-navarro, C.; Coronado, E.; Mart-Gastaldo, C.; Sanchez-Royo, J.F.; Gomez, M.G. Influence of the pH on the synthesis of reduced graphene oxide under hydrothermal conditions. Nanoscale 2012, 4, 3977-3982, doi:10.1039/c2nr30605k.

114. Gotoh, Y.; Hiraiwa, K.; Nagayama, M. In vitro mineralization of osteoblastic cells derived from human bone. Bone Miner. 1990, 8, 239-250, doi:10.1016/0169-6009(90)90109-S.

115. Bhattacharya, G.; Sas, S.; Wadhwa, S.; Mathur, A.; McLaughlin, J.; Roy, S.S. Aloe vera assisted facile green synthesis of reduced graphene oxide for electrochemical and dye removal applications. RSC Adv. 2017, 7, 2668026688, doi:10.1039/c7ra02828h. 